\title{
Seasonal variation of ozone deposition to a tropical rain forest in southwest Amazonia
}

\author{
U. Rummel ${ }^{1, *}$, C. Ammann ${ }^{1, * *}$, G. A. Kirkman ${ }^{1, * * *}$, M. A. L. Moura ${ }^{2}$, T. Foken ${ }^{3}$, M. O. Andreae ${ }^{1}$, and F. X. Meixner ${ }^{1}$ \\ ${ }^{1}$ Max Planck Institute for Chemistry, Biogeochemistry Dept., 55020 Mainz, Germany \\ ${ }^{2}$ Departamento de Meteorologia, Universidade Federal de Alagoas, Maceió, Brazil \\ ${ }^{3}$ University of Bayreuth, Micrometeorology Dept., 95440 Bayreuth, Germany \\ * now at: Richard Assmann Observatory Lindenberg, German Meteorological Service, Germany \\ ** now at: Agroscope ART, Air Pollution and Climate Group, 8046 Zürich, Switzerland \\ *** now at: United Nations Framework Convention on Climate Change, 53179 Bonn, Germany
}

Received: 14 March 2007 - Published in Atmos. Chem. Phys. Discuss.: 30 May 2007

Revised: 1 October 2007 - Accepted: 8 October 2007 - Published: 18 October 2007

\begin{abstract}
Within the project EUropean Studies on Trace gases and Atmospheric CHemistry as a contribution to Large-scale Biosphere-atmosphere experiment in Amazonia (LBA-EUSTACH), we performed tower-based eddy covariance measurements of $\mathrm{O}_{3}$ flux above an Amazonian primary rain forest at the end of the wet and dry season. Ozone deposition revealed distinct seasonal differences in the magnitude and diel variation. In the wet season, the rain forest was an effective $\mathrm{O}_{3}$ sink with a mean daytime (midday) maximum deposition velocity of $2.3 \mathrm{~cm} \mathrm{~s}^{-1}$, and a corresponding $\mathrm{O}_{3}$ flux of $-11 \mathrm{nmol} \mathrm{m}^{-2} \mathrm{~s}^{-1}$. At the end of the dry season, the ozone mixing ratio was about four times higher (up to maximum values of $80 \mathrm{ppb}$ ) than in the wet season, as a consequence of strong regional biomass burning activity. However, the typical maximum daytime deposition flux was very similar to the wet season. This results from a strong limitation of daytime $\mathrm{O}_{3}$ deposition due to reduced plant stomatal aperture as a response to large values of the specific humidity deficit. As a result, the average midday deposition velocity in the dry burning season was only $0.5 \mathrm{~cm} \mathrm{~s}^{-1}$. The large diel ozone variation caused large canopy storage effects that masked the true diel variation of ozone deposition mechanisms in the measured eddy covariance flux, and for which corrections had to be made. In general, stomatal aperture was sufficient to explain the largest part of daytime ozone deposition. However, during nighttime, chemical reaction with nitrogen monoxide (NO) was found to contribute substantially to the $\mathrm{O}_{3}$ sink in the rain forest canopy. Further contributions
\end{abstract}

Correspondence to: U. Rummel

(udo.rummel@dwd.de) were from non-stomatal plant uptake and other processes that could not be clearly identified.

Measurements, made simultaneously on a 22 years old cattle pasture enabled the spatially and temporally direct comparison of $\mathrm{O}_{3}$ dry deposition values from this site with typical vegetation cover of deforested land in southwest Amazonia to the results from the primary rain forest. The mean ozone deposition to the pasture was found to be systematically lower than that to the forest by $30 \%$ in the wet and $18 \%$ in the dry season.

\section{Introduction}

As a secondary pollutant, tropospheric ozone, $\mathrm{O}_{3}$, is formed by the photochemical oxidation of carbon monoxide, $\mathrm{CO}$, and hydrocarbons in the presence of nitrogen oxides, $\mathrm{NO}_{\mathrm{x}}$ (Crutzen, 1979). The highest mixing ratios arise mainly in industrialized areas of the Northern Hemisphere where anthropogenic emissions of precursors are extremely high (Chameides et al., 1992). The gradual increase of $\mathrm{O}_{3}$ together with $\mathrm{CO}$ and methane is a global phenomenon (Crutzen and Andreae, 1990) that represents a substantial environmental problem because of the detrimental impact of high $\mathrm{O}_{3}$ mixing ratios on vegetation and human health. $\mathrm{O}_{3}$ is also a key precursor of the hydroxyl radical $\mathrm{OH}$, the primary oxidant in the troposphere, which is responsible for the removal of many reactive pollutants. Most oxidation of trace gases occurs in the tropical troposphere, where high UV intensities and water vapor concentrations favor the formation

Published by Copernicus Publications on behalf of the European Geosciences Union. 
of $\mathrm{OH}$ by $\mathrm{O}_{3}$ photolysis (Crutzen, 1986). Furthermore, $\mathrm{O}_{3}$ is an important greenhouse gas in the upper troposphere.

In the absence of anthropogenic biomass burning, the seasonal variation of $\mathrm{O}_{3}$ in the atmospheric boundary layer of remote tropical regions is mainly a consequence of photochemical processes and the exchange with both the free troposphere and terrestrial surfaces. During the wet season, convective systems cause an effective $\mathrm{O}_{3}$ entrainment from the free troposphere that leads to a weak net photochemical loss within the boundary layer (Fan et al., 1990; Gregory et al., 1990; Jacob and Wofsy, 1990). Contrastingly, the $\mathrm{O}_{3}$ input from aloft is rather small in the dry season due to the formation of the trade wind inversion by large-scale subsiding air motion under which conditions the net photochemical production can become the dominating $\mathrm{O}_{3}$ source (with surface-emitted volatile organic compounds and $\mathrm{NO}_{\mathrm{x}}$ as precursors; Jacob and Wofsy, 1988). However, in large parts of the tropics, the natural seasonality of the ozone concentration is strongly affected by anthropogenic biomass burning activities during the dry season (e.g. Crutzen et al., 1985; Delany et al., 1985; Kirchhoff et al., 1988; Kirchhoff et al., 1990; Logan and Kirchhoff, 1986). $\mathrm{O}_{3}$ mixing ratios of 50-100 ppb are frequently reached in haze layers at altitudes between 1 and $4 \mathrm{~km}$ (Andreae et al., 1988; Cros et al., 1988). In the vicinity of burning areas of the Brazilian cerrado (savanna), $\mathrm{O}_{3}$ mixing ratios of up to $80 \mathrm{ppb}$ have been found even at the surface (Kirchhoff et al., 1996).

The dry deposition of $\mathrm{O}_{3}$ is one of the most important sinks in the boundary layer ozone budget, counterweighing the sources described above. However, measurements of the $\mathrm{O}_{3}$ dry deposition are up to now very scarce in the tropics, even for the rainforest, its main biome. So far, only one experiment (the wet season Amazonian Boundary Layer Experiment (ABLE) 2B) with continuous direct $\mathrm{O}_{3}$ flux measurements above a tropical rain forest has been reported (Fan et al., 1990), in Central Amazonia. The majority of other related experiments were carried out in the dry season and provide only crude estimates of ozone deposition. They result from atmospheric boundary layer (ABL) or surface layer (SL) budget calculations, which are based on a few vertical profiles of $\mathrm{O}_{3}$ mixing ratios in the northern Congo (Andreae et al., 1992; Cros et al., 1992) and in the central Amazon (e.g. Gregory et al., 1988; Kirchhoff et al., 1988). Direct flux measurements applying an airborne eddy covariance system over the northern Congo were made by Cros et al. (2000). Although these experiments provide valuable flux data on a regional scale, they do not provide much information about the diurnal and seasonal variability of ozone deposition. This information is necessary for understanding the individual mechanisms that regulate the surface deposition of $\mathrm{O}_{3}$, but is presently lacking for the tropical rain forest under dry season conditions.

The present study was carried out as part of the LBAEUSTACH project (EUropean Studies on Trace gases and Atmospheric CHemistry as a contribution to Large-scale
Biosphere-atmosphere experiment in Amazonia, Andreae et al., 2002). In particular, we have addressed the diurnal and seasonal variations of ozone deposition to a tropical rain forest and their controlling mechanisms. We will report on ozone fluxes measured by eddy covariance during campaigns at the end of the wet season (May 1999) and at the end of the dry season (September/October 1999) at a forest tower site in Rondônia, Brazil. Simultaneously with our rain forest experiment, $\mathrm{O}_{3}$ flux measurements were performed by Kirkman et al. (2002) on a $60 \mathrm{~km}$ distant pasture site that was established by deforestation more than 20 years before. By comparing the forest and pasture fluxes under similar environmental conditions, we will assess the impact of deforestation and land-use change on ozone deposition.

\section{Experiment}

\subsection{Measurement site and periods}

The experimental site $\left(10^{\circ} 04^{\prime} 55^{\prime \prime} \mathrm{S}, \quad 61^{\circ} 55^{\prime} 48^{\prime \prime} \mathrm{W}\right.$, $147 \mathrm{~m}$ a.s.1.), a former ABRACOS site, (Gash et al., 1996) is located in the Reserva Biológica Jarú (RBJ), a forest reserve $90 \mathrm{~km}$ north of the city of Ji-Paraná in the state of Rondônia/Brazil (see Fig. 1). The vegetation cover at RBJ, which is owned by the Brazilian Environmental Protection Agency (IBAMA), consists of primary (terra firme) open rain forest with a closed canopy of about $32 \mathrm{~m}$ height. Single trees, jutting above the canopy, may reach up to $45 \mathrm{~m}$. Due to their relevance for turbulence, an effective canopy layer height of $40 \mathrm{~m}$ was defined for the present analysis following Kruijt et al. (1996). The understory consists mainly of palms. Plant species at the measuring site have been characterized by McWilliam et al. (1996). Using an optical device, (LI-COR LAI 2000, USA), a total leaf area index (LAI) of 5.6 was determined (for a discussion of the vertical LAI distribution, see Rummel et al. (2002).

The horizontal extent of the forest cover around the site is partly limited. Within the west-northwest to southeast sector, primary rain forest exists for tens to hundreds of $\mathrm{km}$. In the remaining sector a river (Rio Machado) interrupts the vegetation. The minimum distance to the river (in the southwest direction) is about $400 \mathrm{~m}$. Beyond the river there is a mixture of plantations, secondary growth forest, and remaining patches of primary rain forest. Due to ongoing deforestation and colonization (activities which were promoted over the last 25 years in Rondônia by Brazilian authorities) the resulting characteristic "fishbone" pattern of land-use can be seen on the satellite image (LANDSAT) of Fig. 1.

Rondônia, located at the south-western margin of Amazonia, is characterized by a distinct dry season (peaking in July and August), with most of the rains falling from December to March (see Fig. 2). The monthly rainfall during the two LBA-EUSTACH campaigns (Fig. 2) was similar to the 10year mean, with somewhat less rain in May and a somewhat 


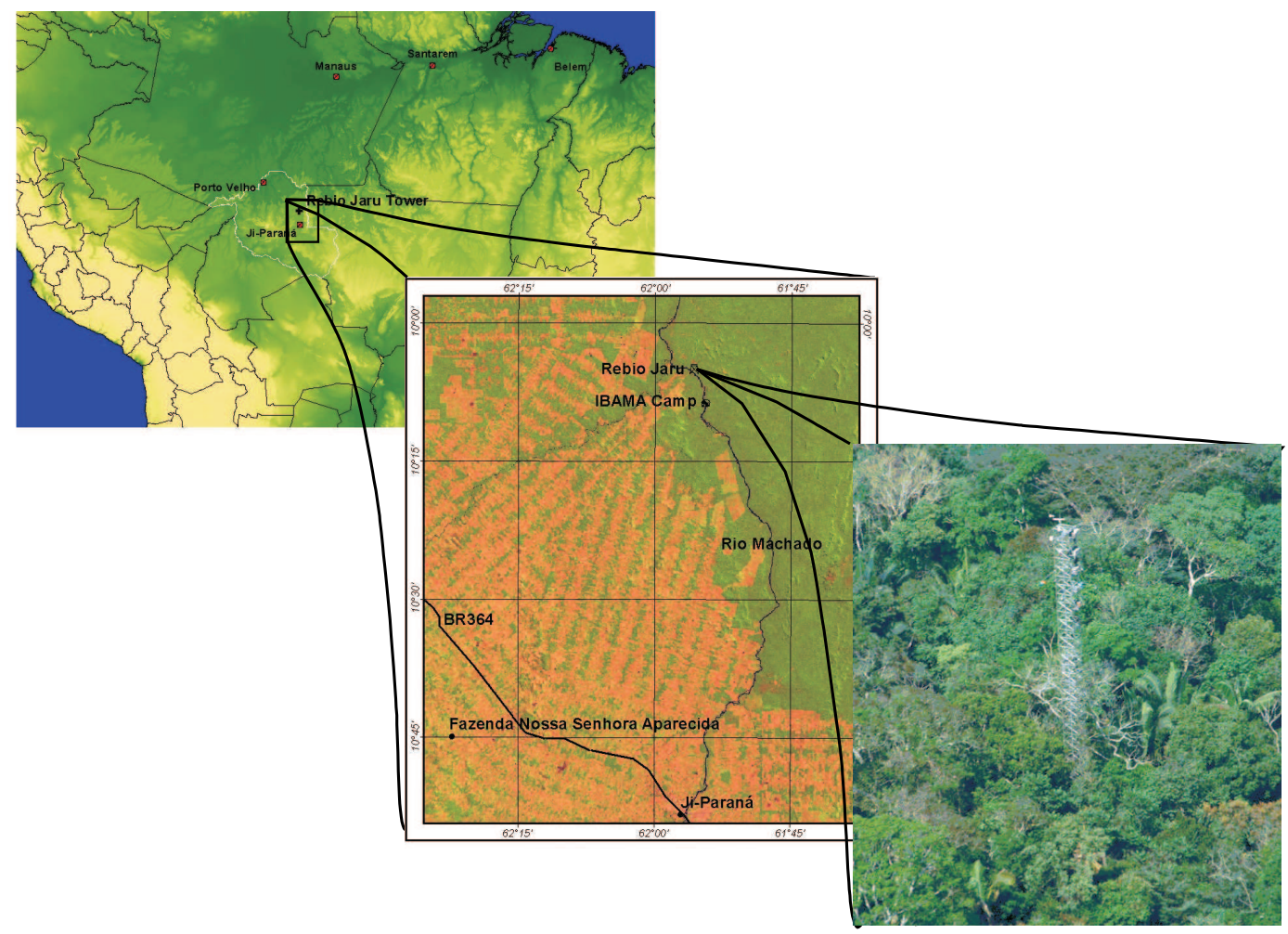

Fig. 1. Map and satellite image (LANDSAT) indicating the location of the LBA-EUSTACH sites, Reserva Biológica Jarú (RBJ), Fazenda Nossa Senhora Aparecida (FNS), and the IBAMA camp in the state of Rondônia/Brazil. The tower site at RBJ $\left(10^{\circ} 04^{\prime} 55^{\prime \prime} \mathrm{S}, 61^{\circ} 55^{\prime} 48^{\prime \prime} \mathrm{W}\right)$ is shown in the lower right image.

wetter September. Our ozone flux measurements were carried out from 4 to 22 May 1999 (LBA-EUSTACH 1) and from 21 September to 20 October 1999 (LBA-EUSTACH 2). The latter campaign was well within the time period of local and regional biomass burning activities.

Results from our measurements of global radiation, air temperature, and humidity, and earlier results on the soil water content in the root layer (Hodnett et al., 1996), show that the conditions during the two measurement periods (at the end of the wet and dry seasons, respectively) were characteristic of the respective peak seasons despite the already changing rain regimes.

The specific humidity deficit $(S H D)$, a quantity characterizing wet and dry seasons, is an important parameter for ozone deposition, because it has a limiting effect on stomatal conductance (Wright et al., 1996). The monthly average value of $S H D$, measured at $51.7 \mathrm{~m}$, for May 1999 was $2.5 \mathrm{~g} \mathrm{~kg}^{-1}$. This is close to the average value of $2.4 \mathrm{~g} \mathrm{~kg}^{-1}$ observed for the peak wet season from January to March for 1992 and 1993 (ABRACOS experiment, see Culf et al., 1996). These values are distinctively lower than the corresponding ABRACOS data for June $\left(3.5 \mathrm{~g} \mathrm{~kg}^{-1}\right)$, which indicate the beginning of the dry season. The average $S H D$ during LBA-EUSTACH 2 was $5.2 \mathrm{~g} \mathrm{~kg}^{-1}$, comparable to

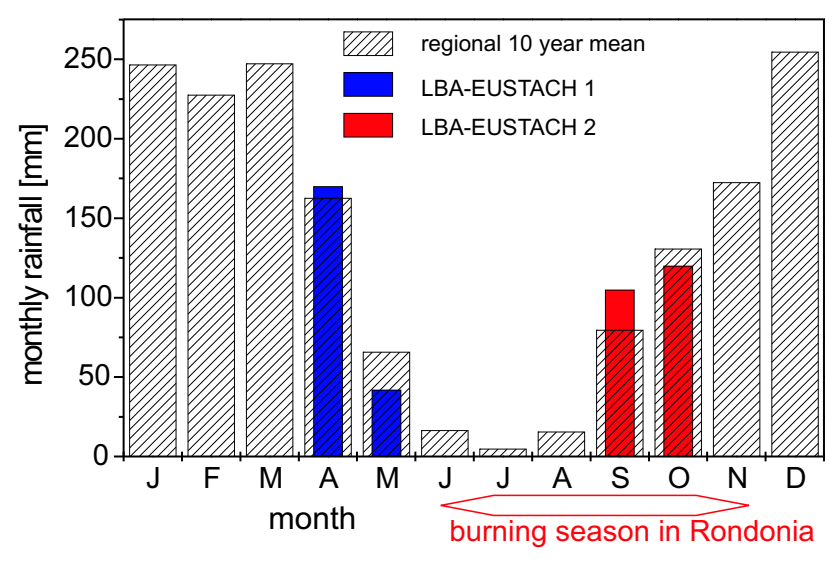

Fig. 2. Ten-year average monthly rainfall distribution from a standard weather station close to RBJ (Gash et al., 1996) and monthly rainfall measured at RBJ during the experimental periods LBAEUSTACH 1 and 2 (April-May and September-October 1999, respectively).

$5 \mathrm{~g} \mathrm{~kg}^{-1}$ for the peak dry season (July and August) of the ABRACOS data. Therefore, the LBA-EUSTACH field campaigns are designated as wet (LBA-EUSTACH 1) and dry season (LBA-EUSTACH 2) experiments in the following. 


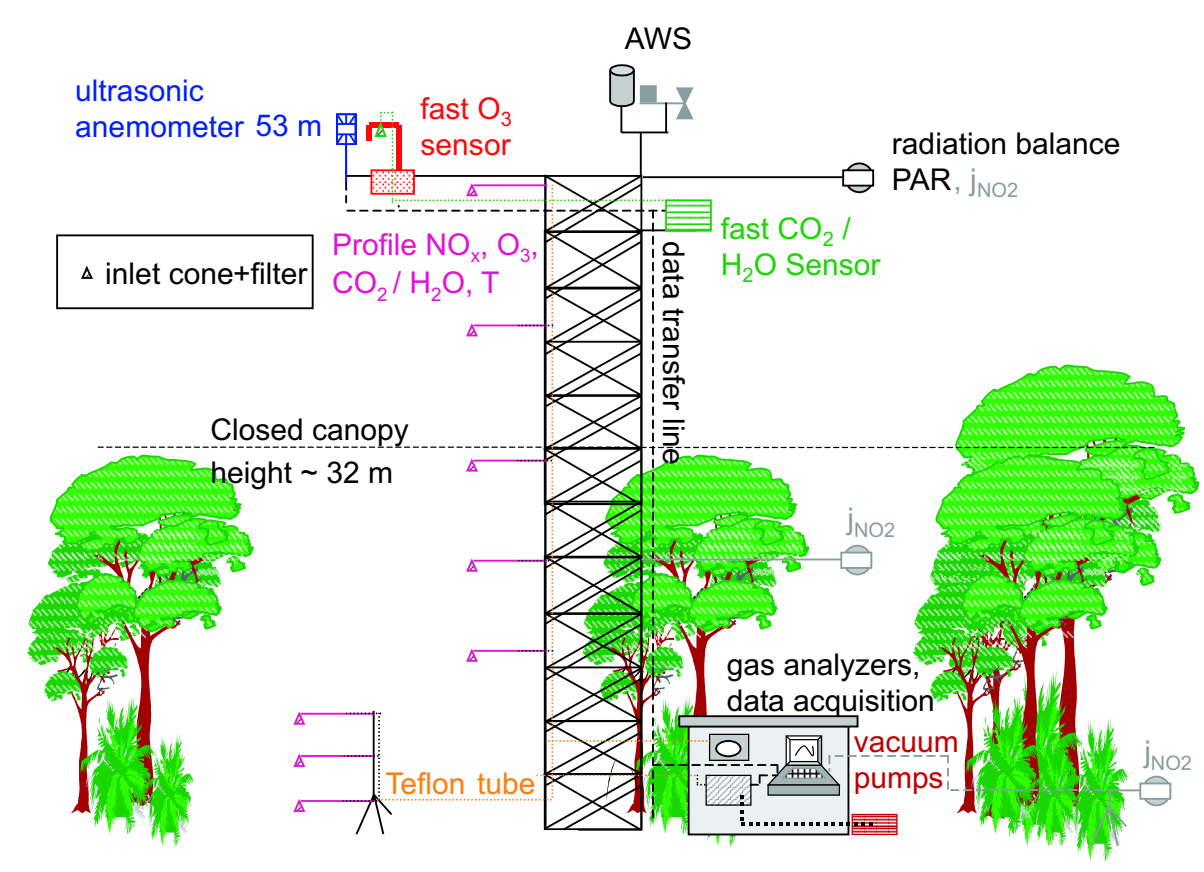

Fig. 3. Scheme of the cumulative experimental setup of the tower site at the Reserva Biológica Jarú (RBJ) during LBA-EUSTACH 1 and 2 campaigns. Measurements performed periodically are displayed in light gray (e.g. $\mathrm{NO}_{2}$ photolysis rate $j_{\mathrm{NO} 2}$ was measured alternately at three heights).

\subsection{Eddy covariance flux system}

A $52 \mathrm{~m}$ high scaffolding tower (see Fig. 1), erected in 1991 (Gash et al., 1996), served as the main platform for the measurements at the RBJ site. A comprehensive scheme of the experimental setup is shown in Fig. 3. The eddy covariance system for trace gas flux measurements was installed on a boom at $53 \mathrm{~m}(=1.33 h ; h$ : effective canopy layer height $)$ extending $4 \mathrm{~m}$ horizontally from the tower. High-frequency data for the eddy covariance technique were continuously sampled at $20.8 \mathrm{~Hz}$. Fluctuations of the three wind velocity components $(u, v, w)$ and virtual temperature $\left(T_{v}\right)$ were measured by a sonic anemometer (Gill Instruments, Solent Research 1012 K55, UK). For $\mathrm{H}_{2} \mathrm{O}$ and $\mathrm{CO}_{2}$ measurements, a closed-path differential infrared absorption analyzer (LICOR LI-6262, USA) with a nominal response time of $0.1 \mathrm{~s}$ was used (see e.g. Ammann, 1999; Aubinet et al., 2000; Moncrieff et al., 1997). The fast $\mathrm{O}_{3}$ analyzer (GFAS, Germany) is based on the surface chemiluminescence reaction of $\mathrm{O}_{3}$ with a coumarin dye layer on an aluminum plate placed in the sample air stream (Ammann, 1999; Güsten et al., 1992; Güsten and Heinrich, 1996). The fast $\mathrm{O}_{3}$ analyzer was mounted on the tower boom close to the sonic anemometer. Sampling air was led to the analyzer by an inlet tube, $0.5 \mathrm{~m}$ in length with an inner diameter of $0.02 \mathrm{~m}$. To prevent flow distortion by the tube, the inlet was separated $0.30 \mathrm{~m}$ from the head of the sonic anemometer. Turbulent flow in the tubing was ensured by a micro fan maintaining a flow rate of $\sim 100 \mathrm{~L} \mathrm{~min}^{-1}$. With this setup, the response time of the $\mathrm{O}_{3}$ analyzer is well below $0.1 \mathrm{~s}$. Since the sensitivity of the analyzer showed a considerable temporal variability, it was calibrated on an hourly basis against the $\mathrm{O}_{3}$ mixing ratio from the uppermost profile measurement (see below).

\subsection{Trace gas profiles}

Vertical profiles of $\mathrm{O}_{3}$ as well as $\mathrm{H}_{2} \mathrm{O}, \mathrm{CO}_{2}, \mathrm{NO}$, and $\mathrm{NO}_{2}$ mixing ratios were measured above and throughout the canopy. The air sampling system consisted of eight $4.35 \mathrm{~mm}$ (inner diameter) TEFLON ${ }^{\circledR}$ tubes connecting the inlets at heights of $0.3 \mathrm{~m}, 1.0 \mathrm{~m}, 4.0 \mathrm{~m}, 11.3 \mathrm{~m}, 20.5 \mathrm{~m}$, $31.3 \mathrm{~m}, 42.2 \mathrm{~m}$, and $51.7 \mathrm{~m}$ to the analyzers in the shelter at the tower base. The tubes were installed within an opaque insulated pipe, which was heated just above ambient air temperature to prevent condensation in the tubing system. All inlets at heights up to $4 \mathrm{~m}$ above ground were attached to a separate tripod located $15 \mathrm{~m}$ northeast of the tower, where the surrounding area was closed off to minimize soil disturbance. All tubes were continuously flushed by a purging pump and air from all heights was sequentially sampled by a TEFLON ${ }^{\circledR}$ valve manifold. Past the manifold, the inlets to each trace gas analyzer were branched off from the main sampling stream. $\mathrm{O}_{3}$ mixing ratios were measured with a UV absorption analyzer (Thermo Instruments TE49C, USA), and $\mathrm{H}_{2} \mathrm{O}$ and $\mathrm{CO}_{2}$ by a second LI-6262 analyzer. A gas phase chemiluminescence analyzer (ECO Physics CLD 780 
TR, Switzerland) was applied for the measurement of NO and $\mathrm{NO}_{2}$ mixing ratios, where the use of a photolytic converter (ECO Physics PLC 760, Switzerland) guaranteed the specific detection of $\mathrm{NO}_{2}$ (see Rummel, 2005). A gas-phase dilution/titration unit (ANSYCO SYCOS K/GPT, Germany) containing a UV lamp as $\mathrm{O}_{3}$ source was used together with pressurized cylinders of zero-air and NO standard (10 ppm) for combined calibrations of the $\mathrm{O}_{3}, \mathrm{NO}$, and $\mathrm{NO}_{2}$ analyzers. Residence times in the tubing system were $1-8 \mathrm{~s}$; correspondingly, mixing ratios of $\mathrm{O}_{3}, \mathrm{NO}$, and $\mathrm{NO}_{2}$ were corrected for the gas-phase reaction $\mathrm{NO}+\mathrm{O}_{3} \rightarrow \mathrm{NO}_{2}+\mathrm{O}_{2}$ (Beier and Schneewind, 1991). Two complete cycles of sequentially sampled profile data were generally averaged to obtain halfhourly data sets of vertical trace gas profiles.

\subsection{Meteorological quantities and $\mathrm{NO}_{2}$ photolysis rate}

An automatic weather station (AWS) at the top of the tower (53m) monitored air temperature $T$ and relative humidity RH (Rotronic MP300, Switzerland), wind speed ws and direction $w d$ (Young 05103-5, USA), precipitation (Campbell ARG100, USA), hydrostatic pressure $p$ (Vaisala PTA427, Finland), and incoming short wave radiation $S_{R}$ (LI-COR LI-200SZ, USA). At the end of both campaigns, the $\mathrm{NO}_{2}$ photolysis rate $j_{\mathrm{NO} 2}$ was measured for a few days at $51.7 \mathrm{~m}$ height by a selective UV radiation sensor (Meteorologie Consult, Germany). These periods were used to derive relationships between $j_{\mathrm{NO} 2}$ above the forest and the simultaneously measured short wave radiation $S_{R}$, which was available for all experimental periods. In addition, $j_{\mathrm{NO} 2}$ was also measured within the canopy at $22 \mathrm{~m}$ and $1 \mathrm{~m}$ height during the dry season campaign. The attenuation of $j_{\mathrm{NO} 2}$ with decreasing height below the canopy top was approximated with an exponential decay function fitted to the measurements at the three heights.

\section{Methods}

\subsection{Eddy covariance data processing}

After an intensive spike and error control of the raw data, half hour averages of eddy covariance fluxes were calculated. Time lags between the signals from sonic anemometers and trace gas analyzers were estimated by determining the maxima of correspondent covariance functions within preset time lag intervals. A linear detrending was applied to the time series followed by a two axis rotation of the wind field coordinates (e.g. Aubinet et al., 2000). Trace gas fluxes were corrected according to Webb et al. (1980) to account for flux contributions caused by air density fluctuations from sensible and latent heat exchange. The short inlet system of the $\mathrm{O}_{3}$ analyzers partly damped the temperature fluctuations (Ammann, 1999) which had to be adequately considered. High frequency flux loss caused by the physical properties of sensors, the setup, and data acquisition was corrected for ac- cording to Moore (1986), Zeller et al. (1989), Lenschow and Raupach (1991), and Horst (2000), using the semi-empirical spectral formulations of Kaimal et al. (1972). Flux loss at low frequencies was estimated with a transfer function after Kristensen (1998) (see Aubinet et al., 2000) to be about 6\% during the daytime, with lower values during the night. However, due to the poor determination of the model spectra used in the low-frequency part for unstable daytime conditions, and the generally small effect, a low-frequency correction was not applied.

To avoid the influence of rapidly changing environmental conditions on our analysis, a stationarity test after Foken and Wichura (1996) was applied to all derived variances and covariances. Data were rejected if the (co)variance averaged over 30 min deviated more than $100 \%$ from the average of the fluxes obtained from 10-min subintervals (instead of 5-min subintervals proposed by Foken and Wichura, 1996). Here, the unstable stratification within the tropical boundary layer and the occurrence of coherent turbulent structures are taken into account by the longer subintervals (see Rummel, 2005). Two additional data rejection criteria were considered. The first one relates to calm conditions without fully developed turbulence, and excludes all cases where the friction velocity was lower than a critical value $u_{* \text { crit }} \approx 0.01 \mathrm{~m} \mathrm{~s}^{-1}$. This threshold was found to be high enough to reject most cases affected by non-turbulent conditions and low enough to avoid a strong selection-related bias towards windy conditions during nighttime.

The second criterion concerns periods with disturbed upwind fetch. Footprint analysis for the eddy covariance fluxes was performed by the model of Schmid (1994). The 80\% flux source areas were calculated separately for daytime and nighttime conditions. The results for the wet and the dry season campaign are shown in the form of two-dimensional frequency distributions in Fig. 4. A general dominance of easterly over westerly wind components is obvious. During daytime, unstable stratification ensured rather small source areas. For $90 \%$ of all daytime cases, the flux source area was not at all or barely influenced by the river. Only data with wind directions in the sector $225^{\circ}-280^{\circ}$ were excluded from the analysis, because of flow distortion by the geometric structures of the scaffolding tower itself. During nighttime the situation was clearly different. Due to the prevailing very stable stratification, a significantly higher percentage of flux measurements was influenced by the Rio Machado and the forest/pasture vegetation mix west of it. Therefore, all cases with wind directions in the sector $150^{\circ}-300^{\circ}$ were excluded from our analysis. After rigorous application of all rejection criteria and the exclusion of periods of instrument failure, the overall daytime (nighttime) data coverage was reduced to $74 \%$ (29\%) and 66\% (23\%) during the wet and the dry season experimental periods, respectively.

Measurements of trace gas fluxes by eddy covariance are often affected by the instrumental noise of the gas sensor. Under the assumption of "ideal white noise", which does not 

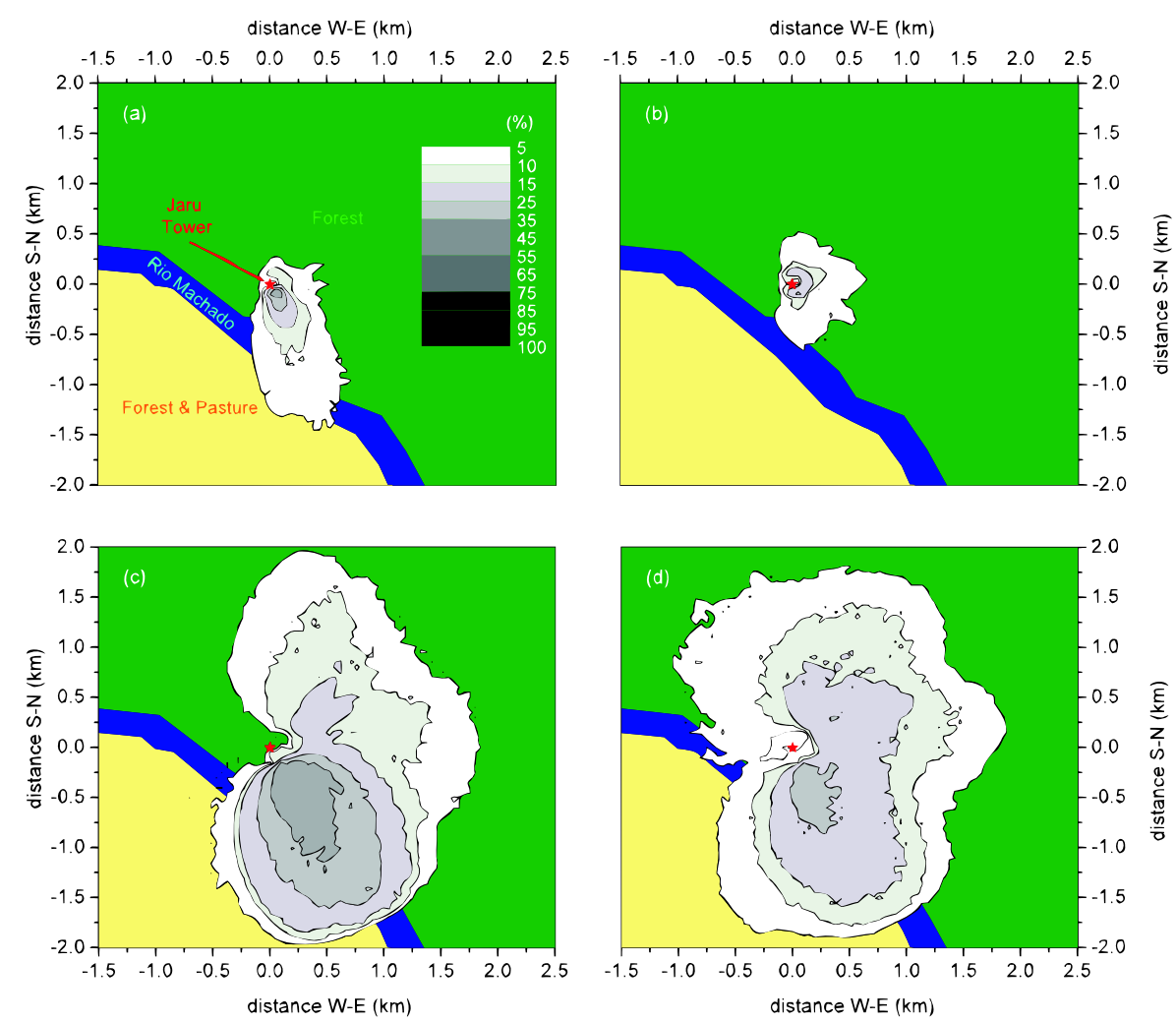

Fig. 4. Two-dimensional frequency distributions (percent) showing how often each point in the terrain surrounding the tower was contributing to the $80 \%$ source area of any flux measured at the $53 \mathrm{~m}$ level of the RBJ tower. The wet and the dry season experiment, daytime conditions are shown in panels (a) and (b), and those of nighttime in panels (c) and (d). The red star denotes the position of the RBJ tower at $(0 \mathrm{~km}$; $0 \mathrm{~km}$ ). In 1999, there was primary rain forest west of the river, while east of it a mixture of forest and pasture prevailed (see Sect. 2.1).

correlate with the vertical velocity fluctuations, there is no systematic effect on the trace gas flux. But the associated statistical error directly affects the magnitude of the minimal resolvable flux. A procedure proposed by Lenschow and Kristensen (1985) was used to calculate the effective detection limit for the ozone flux to be $\sim 0.45 \mathrm{nmol} \mathrm{m}^{-2} \mathrm{~s}^{-1}$.

\subsection{Ozone budget}

Measuring turbulent fluxes of reactive trace gases like ozone above tall vegetation canopies requires the determination of additional terms in the corresponding mass balance equation. This is necessary to relate the measurements to the actual $\mathrm{O}_{3}$ removal (i) at plant and soil surfaces, or (ii) by chemical reactions within the canopy. Assuming horizontal homogeneity (see Coppin et al., 1986; Raupach and Shaw, 1982), the $\mathrm{O}_{3}$ mass balance equation is given by:

$$
\begin{aligned}
& F_{\mathrm{O}_{3}}\left(z_{m}\right)+\frac{\partial}{\partial t} \int_{0}^{z_{m}}\left[\mathrm{O}_{3}\right](z) d z \\
& =\int_{0}^{z_{m}} C h_{\text {net }}(z) d z+\int_{0}^{z_{m}} D_{S}(z) d z+F_{\mathrm{O}_{3}}(0)
\end{aligned}
$$

where $F_{\mathrm{O}_{3}}\left(z_{m}\right)$ denotes the turbulent ozone flux at the measuring height $z_{m}=53 \mathrm{~m}$. The second term on the left side represents the vertically integrated storage change within the air column between the soil surface and the measuring height. Since it does not represent a removal process, but only an intermediate storage, the measured ozone flux has to be corrected for this effect for the correct determination of the ozone deposition processes. The storage change was calculated from the temporal change of the measured ozone profiles (see Sect. 2.3 and Fig. 3). The right hand side of Eq. (1) contains the terms of different $\mathrm{O}_{3}$ removal pathways. $F_{\mathrm{O}_{3}}(0)$ is the soil deposition flux at the forest floor. It was estimated on the basis of measurements by Gut et al. (2002b), which were performed simultaneously with our flux measurements. $D_{S}(z)$ is the actual deposition to plant surfaces. $C h_{\text {net }}(\mathrm{z})$ represents the height-dependent net effect of chemical processes, i.e. the difference between chemical production and loss rates. Based on the available mixing ratio measurements, we confine $C h_{\text {net }}(z)$ to the photochemical triad of $\mathrm{NO}-\mathrm{NO}_{2}-$ $\mathrm{O}_{3}$ (see Meixner et al., 1997):

$$
\begin{aligned}
& \mathrm{NO}_{2}+h v \stackrel{j_{\mathrm{NO} 2}}{\longrightarrow} \mathrm{NO}+\mathrm{O} \\
& \mathrm{O}+\mathrm{O}_{2} \stackrel{k_{1}}{\longrightarrow} \mathrm{O}_{3}
\end{aligned}
$$


$\mathrm{NO}+\mathrm{O}_{3} \stackrel{k_{2}}{\longrightarrow} \mathrm{NO}_{2}+\mathrm{O}_{2}$

The second Reaction (R2) is very fast and can be considered as immediate. Therefore in this simplified system ozone is formed as a direct result of $\mathrm{NO}_{2}$ photolysis by solar radiation $(\lambda \leq 420 \mathrm{~nm})$. The oxidation of $\mathrm{NO}$ by $\mathrm{O}_{3}$ (Reaction R3) reforms $\mathrm{NO}_{2}$. The reaction rate of Reaction (R3) was calculated as $k_{2}=17 / T \times \exp (-1450 / T)$ in units of $\mathrm{ppb}^{-1} \mathrm{~s}^{-1}$. Despite their likely importance for ozone formation above the tropical forest (e.g. Jacob and Wofsy, 1988; Jacob and Wofsy, 1990), the influence of peroxy radicals $\mathrm{RO}_{2}$ was not considered, due to the complete lack of experimental data about their mixing ratios.

\subsection{Canopy scale resistances}

For trace gases like ozone, which (i) are exclusively depositing, (ii) reveal a zero substrate mixing ratio (cf. Laisk et al., 1989), and (iii) for which a negligible net effect of sources and sinks between the surface and the reference height $z_{m}$ can be assumed, the concept of dry deposition velocity $\left(v_{d}\right)$ can be applied:

$v_{d}=-\frac{F_{\mathrm{O}_{3}}\left(z_{m}\right)}{\left[\mathrm{O}_{3}\right]\left(z_{m}\right)}$

Normalizing the flux $F_{\mathrm{O}_{3}}$ by the mixing ratio $\left[\mathrm{O}_{3}\right]$ at the reference height permits the study of parameters affecting deposition rates independent of ambient $\mathrm{O}_{3}$ mixing ratios. It also makes it possible to compare deposition rates measured above different surfaces. The simple "big leaf" multiple resistance approach (e.g. Hicks et al., 1987) separates the surface-specific limitations to dry deposition from the aerodynamic limitations. The reciprocal of $v_{d}$, the total resistance to ozone deposition $R_{t}$ is split up into a serial alignment of the aerodynamic resistances $R_{a}$ and $R_{b}$, and the bulk canopy resistance $R_{c}$ :

$$
\frac{1}{v_{d}}=R_{t}=R_{a}+R_{b}+R_{c}
$$

$R_{a}$, which is often called the "atmospheric" or "turbulent aerodynamic" resistance, characterizes the turbulent ozone transfer between $z_{m}$ and the height $d+z_{0}$ :

$R_{a}=\frac{1}{k u_{*}}\left(\ln \left(\frac{z-d}{z_{0}}\right)-\Psi_{\mathrm{O}_{3}}\left(\frac{z-d}{L}, \frac{z_{0}}{L}\right)\right)$

Here, $z_{0}$ is the average roughness length for momentum and $d$ is the zero-plane displacement height, which were determined to $1.3 \mathrm{~m}$ and $34 \mathrm{~m}$, respectively, by a formulation of Raupach (1994) relying on canopy height and leaf area index (LAI). Furthermore, $k$ is the von Kármán constant (0.4), $L$ is the Obukhov length, and $\Psi_{\mathrm{O}_{3}}$ is the integrated similarity function (stability correction) for $\mathrm{O}_{3}$ assumed to be equivalent to that for sensible heat $\Psi_{H}$ (e.g. Ammann, 1999). $R_{b}$, which is often called "boundary layer" or "quasi-laminar boundary layer" resistance, is an "excess" aerodynamic resistance (Baldocchi et al., 1987). It is introduced, because in the quasi-laminar boundary layer close to surfaces, mass and energy transfer are limited by molecular diffusion, whereas momentum transfer is dominated by the pressure drag:

$R_{b}=\ln \left(\frac{z_{0}}{z_{0, \mathrm{O}_{3}}}\right) \frac{1}{k u_{*}}\left(\frac{S c}{P r}\right)^{n}$

The Schmidt number $(S c)$ for ozone is about 1.07 and the Prandtl number $(\mathrm{Pr})$ is 0.72 . Following Hicks et al. (1987) the following parameter settings were used: $\ln \left(z_{0} / z_{0, O_{3}}\right)=\ln \left(z_{0} / z_{0, H}\right) \approx 2$ and $n=2 / 3$. The bulk canopy resistance $R_{c}$, determined as the difference between $R_{t}$ and the sum of aerodynamic resistances $\left(R_{a}+R_{b}\right)$, contains the contributions of all deposition pathways occurring within the canopy. These may consist of (i) the transfer through the stomatal apertures of leaves and subsequent transfer into the mesophyll tissue, (ii) transfer to the leaf cuticle or other outer plant surfaces (e.g. bark), (iii) transfer to the soil surface (including litter), and (iv) consumption by chemical reactions in the canopy air space.

To get an independent estimate of the canopy bulk stomatal resistance $\left(R_{s, \mathrm{O}_{3}}\right)$, a modified Jarvis-type model (Jarvis, 1976) was employed:

$R_{s, \mathrm{O}_{3}}=\frac{D_{\mathrm{H}_{2} \mathrm{O}}}{D_{\mathrm{O}_{3}}}\left[G_{s, \max } \operatorname{LAI} f(S H D) f(T) f\left(S_{R}\right)\right]^{-1}$

Wright et al. (1996) optimized the model for the vegetation at the RBJ site. They applied a non-linear least square optimization to calibrate the product of maximal stomatal conductance $G_{s, \max }$, LAI, and functional relationships for specific humidity deficit $(S H D)$, temperature $(T)$, and short wave radiation $\left(S_{R}\right)$ using canopy resistance values determined by the Penman-Monteith formulation (Monteith and Unsworth, 1990). Here, we applied the parameterization originally derived for $\mathrm{H}_{2} \mathrm{O}$ by using ambient data measured by the automatic weather station at the RBJ tower top and by taking the different molecular diffusivities for $\mathrm{O}_{3}$ and $\mathrm{H}_{2} \mathrm{O}$ into account.

\section{Results}

\subsection{Ambient conditions}

In the following, diurnal and seasonal characteristics of meteorological conditions and ozone deposition are displayed as mean diel variations. For this purpose, median values were used because they are less affected by extreme outliers than are arithmetic averages. Mean daytime and nighttime values of fluxes and other quantities were calculated for 07:0017:00 LT (local time) and 17:00-07:00 LT, respectively. The mean diel variations of $S_{R}, T$, and $S H D$ at $51.7 \mathrm{~m}$ (tower top) for both LBA-EUSTACH experiments are shown in Fig. 5. 

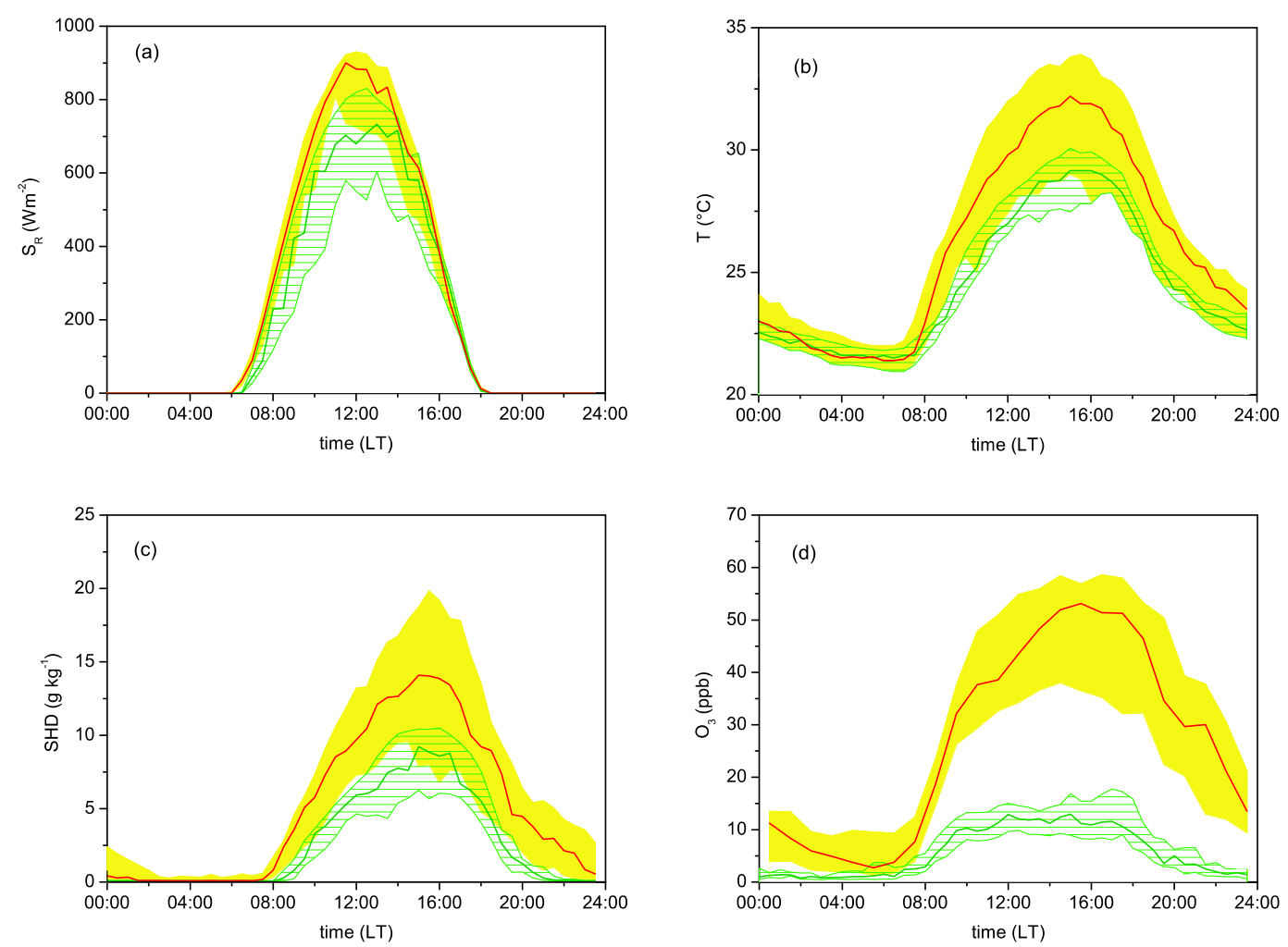

Fig. 5. Diel variation of (a) incoming short-wave radiation, (b) air temperature, (c) specific humidity deficit, and (d) ozone mixing ratio on the RBJ tower at $51.7 \mathrm{~m}$ : Medians (dark green line) and inter- quartile range IQR (green hatched area) for the wet season experiment; medians (red line) and IQR (yellow area) for the dry season experiment.
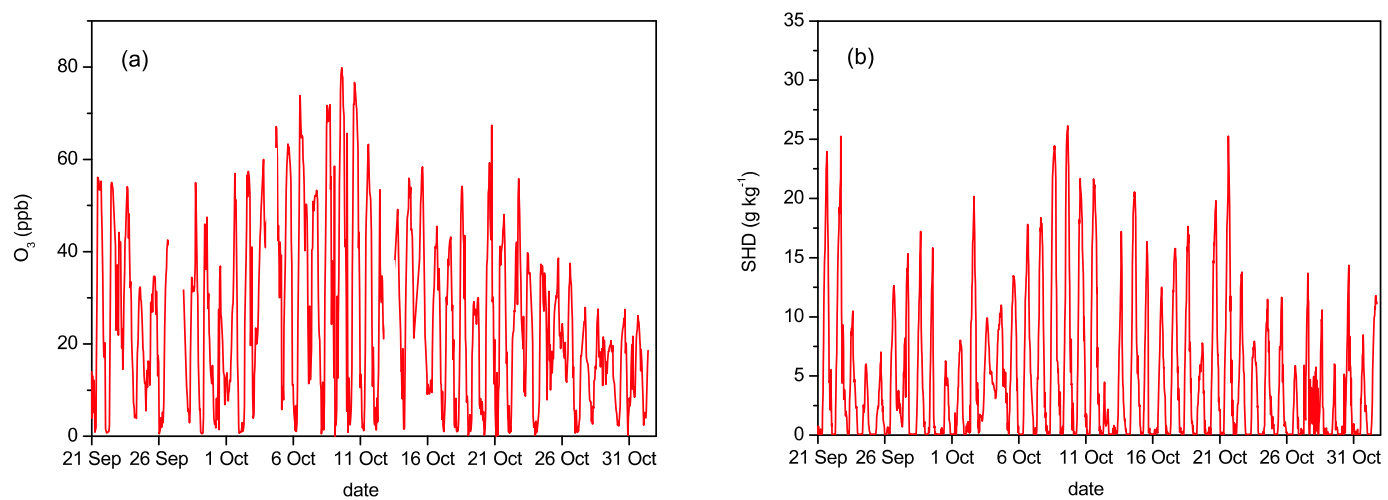

Fig. 6. Time series of (a) $\mathrm{O}_{3}$ mixing ratio and (b) specific humidity deficit at the RBJ tower during the dry season campaign (21 September to 1 November 1999).

All quantities show a considerably larger diel amplitude during the dry season experiment. Only wind speed (not displayed) was very similar for both campaigns with generally moderate values of $0.5-1.5 \mathrm{~m} \mathrm{~s}^{-1}$ during night and $1-2 \mathrm{~m} \mathrm{~s}^{-1}$ during daytime.

The mean diel variations of the $\mathrm{O}_{3}$ mixing ratio (Fig. 5d) refer also to the top of the RBJ tower $(51.7 \mathrm{~m})$, which is approx. $12 \mathrm{~m}$ above the effective canopy height $(h)$. Mixing ratios in the dry season are higher by a factor of about four than in the wet season (typical daytime maxima of $50 \mathrm{ppb}$ and $12 \mathrm{ppb}$, respectively). The mean diel variation in both periods is characterized by a fast increase in the morning hours. The decrease after sunset (18:00 LT) is slower in the dry season leading to a more asymmetric diel course.

Besides substantial differences between the seasons, $\mathrm{O}_{3}$ mixing ratios exhibit also marked intra-seasonal variations 
during the burning season experiment LBA-EUSTACH 2. Corresponding time series of $\mathrm{O}_{3}$ mixing ratio and the specific humidity deficit are shown in Fig. 6. The highest mixing ratios (up to $80 \mathrm{ppb}$ ) occurred at the end of a dry and hot period (2-12 October) lacking any precipitation and with a steady increase of $S H D$. After that period, the $\mathrm{O}_{3}$ mixing ratio continuously decreased to the end of October, when $\mathrm{O}_{3}$ levels reached those at the end of the wet season (see Fig. 5d). Considering only daytime values, the time series of the $\mathrm{O}_{3}$ mixing ratio and $S H D$ show very similar behavior throughout the whole experiment.

For a more direct comparison of the ozone mixing ratio and $S H D$, a scatter plot of both quantities, averaged between 10:00 LT and 18:00 LT (when maximum values occurred) is displayed in Fig. 7 for both experiments. Whereas in the wet season ozone concentration shows only a weak dependence within the limited SHD range, both quantities exhibit a clear positive correlation in the dry season with intensified biomass burning. For the last days of the dry season campaign (25 to 31 October), data points tend towards those of the wet season campaign indicating that the seasonal transition might have already started.

\subsection{Ozone flux and deposition budget terms}

The measured eddy covariance fluxes above the canopy were analyzed in combination with the budget terms given in Eq. (1). Mean diel cycles of the budget terms for both seasons are displayed in Figs. 8c and d. The storage term was calculated from the profile measurements throughout the canopy layer. The ozone concentrations at four out of the eight measured profile levels are shown in Figs. 8a and b. Besides the large differences in the amplitudes of the absolute ozone concentration (note different y-scale), the data also show a stronger damping of the diel cycle in the lower part of the canopy $(11.3 \mathrm{~m}$ and $1.0 \mathrm{~m})$ for the wet-season experiment. In that season, the storage change was rather small compared to the measured $\mathrm{O}_{3}$ flux, and therefore the latter was very similar to the effective deposition flux. During the dry season experimental period, the storage term was considerably enhanced as a consequence of the larger diel variation of $\mathrm{O}_{3}$ above and within the canopy. Around 10:30 LT, the $\mathrm{O}_{3}$ storage term was as large as $54 \%$ of the measured flux. This implies a remarkable discrepancy between the measured $\mathrm{O}_{3}$ flux (amount of $\mathrm{O}_{3}$ which was transported downward through the plane of the measuring height) and the actual deposition flux (removal of ozone).

The storage-corrected $\mathrm{O}_{3}$ flux (left side of Eq. 1), representing the relevant deposition flux, shows similar daytime peak values between 12:00 and 14:00 LT in both seasons (Figs. 8c, d) despite the four-fold higher $\mathrm{O}_{3}$ mixing ratio in the dry season (Fig. 5d). The mean daytime flux showed a moderate increase of $32 \%$ from $-5.0 \mathrm{nmol} \mathrm{m}^{-2} \mathrm{~s}^{-1}$ (wet) to $-6.6 \mathrm{nmol} \mathrm{m}^{-2} \mathrm{~s}^{-1}$ (dry) due to higher values in the morning and evening hours. However, the major difference was

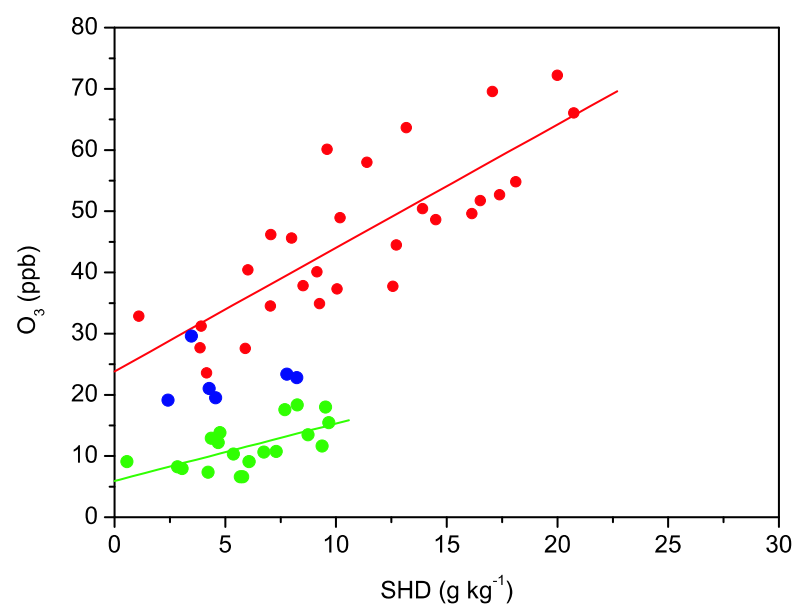

Fig. 7. Average $\mathrm{O}_{3}$ mixing ratio versus average specific humidity deficit at the RBJ tower during the wet season experiment (green) and the dry season experiment (21 September to 20 October: red; 25 to 31 October: blue). Data points represent daytime averages between 10:00 LT and 18:00 LT.

observed during the night. In the wet season, nighttime fluxes are mostly very low, whereas in the dry (burning) season, a considerable part of the diel $\mathrm{O}_{3}$ deposition occurs at night (especially during the first half). Between 19:00 LT and 20:00 LT, the values of the $\mathrm{O}_{3}$ deposition flux are comparable to its daytime maximum. The mean nighttime flux of $-4.0 \mathrm{nmol} \mathrm{m}^{-2} \mathrm{~s}^{-1}$ accounts for $61 \%$ of the corresponding daytime value. For the wet season period with a mean nocturnal flux of $-0.4 \mathrm{nmol} \mathrm{m}^{-2} \mathrm{~s}^{-1}$ this percentage is only $8 \%$ (see Table 1).

During the wet season experiment (Fig. 8c), daytime budget terms of soil deposition and net chemistry were practically negligible compared to the total $\mathrm{O}_{3}$ deposition flux. This clearly indicates that plant uptake is the dominating removal process. During night, the calculated chemical loss partly exceeds the storage corrected flux, which may be attributed to the considerably large uncertainty of the flux and profile measurements, when $\mathrm{O}_{3}$ sensors are close to their detection limits. During the dry season experiment the chemical term was generally enhanced due to higher $\mathrm{O}_{3}$, but also NO mixing ratios (see Andreae et al., 2002). Particularly during night, the chemical term explains a considerable part (in the second half even the major part) of the ozone deposition (Fig. 8d). During daytime, the photolysis of $\mathrm{NO}_{2}$ above the canopy and in the upper crown layer represented a source effect that compensated or temporally even dominated the ozone loss by reaction with NO.

\subsection{Deposition velocity and canopy scale resistances}

The ozone deposition velocity was calculated as the ratio of the storage-corrected $\mathrm{O}_{3}$ flux (i.e. the $\mathrm{O}_{3}$ deposition flux) and the $\mathrm{O}_{3}$ mixing ratio at the top of the RBJ tower $(53 \mathrm{~m})$. The 
Table 1. A compilation of mean (median) ozone flux and deposition velocities, $v_{d}$, observed over tropical rain forests from this and earlier studies. Values in italics refer to measured $\mathrm{O}_{3}$ fluxes above the canopy (without storage term correction).

\begin{tabular}{|c|c|c|c|c|c|c|c|c|}
\hline \multirow{2}{*}{ location } & \multirow{2}{*}{ Season } & \multirow{2}{*}{ method $^{\mathrm{a}}$} & \multicolumn{3}{|c|}{ flux $\left(\mathrm{nmol} \mathrm{m} \mathrm{m}^{-2} \mathrm{~s}^{-1}\right)$} & \multicolumn{3}{|c|}{$v_{d}\left(\mathrm{~cm} \mathrm{~s}^{-1}\right)$} \\
\hline & & & morning ${ }^{\mathrm{b}}$ & day $^{\mathrm{c}}$ & night $^{\mathrm{d}}$ & morning ${ }^{b}$ & day ${ }^{\mathrm{c}}$ & night $^{\mathrm{d}}$ \\
\hline $\begin{array}{l}\text { South west Amazonia } \\
\text { LBA-EUSTACH } 1^{\mathrm{e}}\end{array}$ & wet (end) & $\mathrm{EC}$ & $\begin{array}{l}-5.8 \\
-6.6\end{array}$ & $\begin{array}{l}-5.0 \\
-5.6\end{array}$ & $\begin{array}{l}-0.4 \\
-0.3\end{array}$ & $\begin{array}{l}1.4 \\
1.5\end{array}$ & $\begin{array}{l}1.1 \\
1.2\end{array}$ & $\begin{array}{l}0.5 \\
0.3\end{array}$ \\
\hline \multirow{3}{*}{$\begin{array}{l}\text { South west Amazonia } \\
\text { LBA-EUSTACH } 2^{\mathrm{e}}\end{array}$} & \multirow{3}{*}{ dry (end) } & $\begin{array}{l}\mathrm{EC} \\
\text { all data }\end{array}$ & $\begin{array}{l}-7.7 \\
-11.1\end{array}$ & $\begin{array}{l}-6.6 \\
-8.6\end{array}$ & $\begin{array}{l}-4.0 \\
-2.4\end{array}$ & $\begin{array}{l}0.6 \\
0.8\end{array}$ & $\begin{array}{l}0.5 \\
0.7\end{array}$ & $\begin{array}{l}0.6 \\
0.4\end{array}$ \\
\hline & & $\begin{array}{l}\mathrm{EC} \\
\text { high } S H D\end{array}$ & & $\begin{array}{l}-4.8 \\
-6.6\end{array}$ & $\begin{array}{l}-4.5 \\
-2.1\end{array}$ & & $\begin{array}{l}0.3 \\
0.5\end{array}$ & $\begin{array}{l}0.4 \\
0.3\end{array}$ \\
\hline & & $\begin{array}{l}\mathrm{EC} \\
\text { low } S H D\end{array}$ & & $\begin{array}{l}-8.9 \\
-10.9\end{array}$ & $\begin{array}{l}-4.0 \\
-3.2\end{array}$ & & $\begin{array}{l}0.8 \\
1.0\end{array}$ & $\begin{array}{l}0.8 \\
0.8\end{array}$ \\
\hline $\begin{array}{l}\text { Central Amazonia } \\
\text { Fan et al. (1990) }\end{array}$ & wet & $\mathrm{EC}$ & & -3.8 & -0.37 & & 1.8 & 0.26 \\
\hline $\begin{array}{l}\text { Central Amazonia } \\
\text { Gregory et al. (1988) }\end{array}$ & dry & $\mathrm{ABL}$ & -27 & & & 5 & & \\
\hline $\begin{array}{l}\text { Northern Congo } \\
\text { Cros et al. (1992) }\end{array}$ & dry (end) & $\mathrm{ABL}$ & -15 & & & 5 & & \\
\hline $\begin{array}{l}\text { Congo/Central } \\
\text { African Republic } \\
\text { Cros et al. (2000) }\end{array}$ & dry (begin) & $\begin{array}{l}\mathrm{EC} \\
\mathrm{ABL}\end{array}$ & $\begin{array}{l}-13.1 \\
-14.3\end{array}$ & & & 1.5 & & \\
\hline $\begin{array}{l}\text { Central Amazonia, } \\
\text { Kirchhoff et al. (1988) }\end{array}$ & dry & $\mathrm{G}, \mathrm{ABL}$ & & -40 & -18 & & & \\
\hline $\begin{array}{l}\text { Northern Congo } \\
\text { Andreae et al. (1992) }\end{array}$ & dry (end) & $\mathrm{ABL}$ & & & -2.5 & & & 1.2 \\
\hline
\end{tabular}

a EC: eddy covariance; G: gradient; ABL: atmospheric boundary layer budget estimate;

b Mean value between 08:00 and 13:00 LT corresponding to Gregory et al. (1988) and Cros et al. (2000)

c Mean value between 07:00 and 17:00 LT corresponding to Fan et al. (1990)

d Mean value between 17:00 and 07:00 LT corresponding to Fan et al. (1990), Kirchhoff et al. (1988), and Andreae et al. (1992).

e All mean values for the LBA-EUSTACH experiments are expressed in medians.

diel variation of the mean $\mathrm{O}_{3}$ deposition velocity $\left(v_{d}\right)$ is displayed in Fig. 8e and Fig. 8f for both experimental periods. As for the $\mathrm{O}_{3}$ deposition flux, the diel variation of the mean deposition velocity during the wet season campaign shows an almost symmetrical form, reaching a noon-time maximum of up to $2 \mathrm{~cm} \mathrm{~s}^{-1}$. The mean nighttime deposition velocity $\left(0.5 \mathrm{~cm} \mathrm{~s}^{-1}\right)$ is about $46 \%$ of the mean daytime value $\left(1.1 \mathrm{~cm} \mathrm{~s}^{-1}\right)$. The large variability of the nocturnal $v_{d}$ data is due to the uncertainty of the ratio of two small values $\left(\mathrm{O}_{3}\right.$ flux and mixing ratio). During the dry season campaign, the diel cycle of $v_{d}$ is much more asymmetric with two distinct maxima, one in the late night (around 04:00 LT) and another right after sunrise (07:30 LT). In the following hours, the deposition velocity decreases to a minimum at sunset. The mean daytime value of $v_{d}=0.5 \mathrm{~cm} \mathrm{~s}^{-1}$ is rather low, and very similar to the mean nighttime value $\left(0.6 \mathrm{~cm} \mathrm{~s}^{-1}\right)$, bearing in mind the higher uncertainty for the latter value (see Table 1).

In order to separate the bulk canopy processes of $\mathrm{O}_{3}$ deposition from the aerodynamic limitations, the total resistance $R_{t}$ (reciprocal of deposition velocity $v_{d}$ ) was broken down into the individual resistances $R_{a}, R_{b}$, and $R_{c}$ according to
Eqs. (3) to (5). Figure 9 displays the calculated resistances for both experimental periods. Turbulent aerodynamic $R_{a}$ and quasi laminar boundary layer $R_{b}$ resistances show no significant differences between the seasons. In both cases the mean daytime $R_{a}+R_{b}$ was about $30 \mathrm{~s} \mathrm{~m}^{-1}$. During night, the mean $R_{a}+R_{b}$ of about $300 \mathrm{~s} \mathrm{~m}^{-1}$ during the wet season period was higher than the mean of $180 \mathrm{~s} \mathrm{~m}^{-1}$ for the dry season experiment. The bulk canopy resistance $R_{c}=R_{t}-\left(R_{a}+R_{b}\right)$ is only shown for daytime hours, since the large relative uncertainty of all right-hand terms (due to weak turbulence and small fluxes and mixing ratios) prevents a meaningful determination at nighttime. To a minor extent, $R_{c}$ data right after sunrise and just before sunset also reveal significant uncertainties for similar reasons. For the wet season experiment, the daytime variation of mean $R_{c}$ shows a near-symmetrical form similar to the diel variation of the $\mathrm{O}_{3}$ flux. A daytime mean value of $R_{c}=55 \mathrm{~s} \mathrm{~m}^{-1}$ is observed. In great contrast, $R_{c}$ shows a strong diurnal trend during the late dry season. It increases from low values (similar to wet season values) in the early morning up to about $500 \mathrm{~s} \mathrm{~m}^{-1}$ before sunset. The daytime mean is about $170 \mathrm{~s} \mathrm{~m}^{-1}$. 

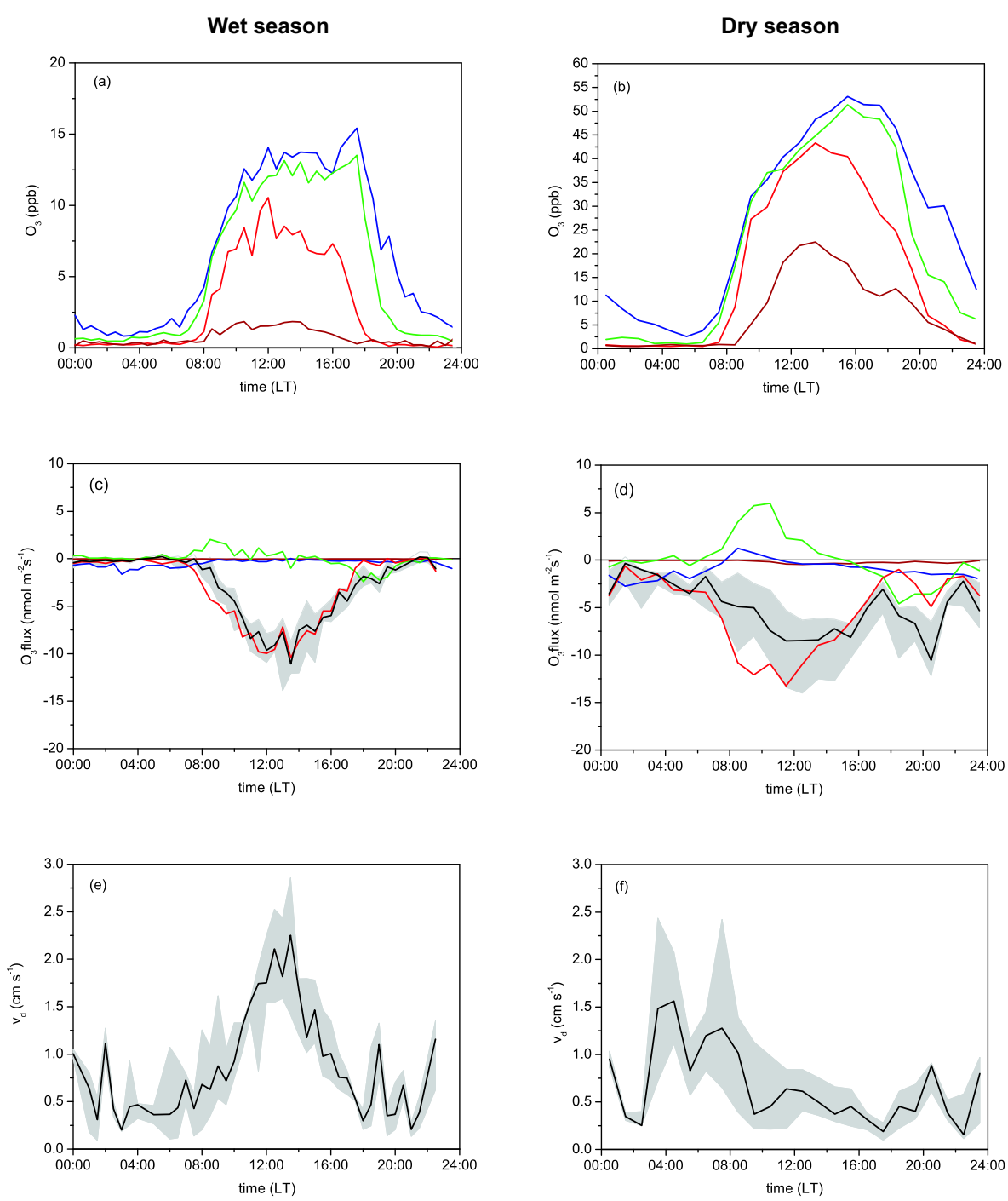

Fig. 8. Diel variation of quantities related to ozone deposition (medians) during the wet season experiment (left panels) and the dry season experiment (right panels). Gray areas indicate the inter-quartile-range (IQR) of selected quantities. Panels (a) and (b): $\mathrm{O}_{3}$ mixing ratio at $51.7 \mathrm{~m}$ (blue), $31.3 \mathrm{~m}$ (green), $11.3 \mathrm{~m}$ (red), and $1 \mathrm{~m}$ (brown); Panels (c) and (d): measured $\mathrm{O}_{3}$ flux (red), $\mathrm{O}_{3}$ storage within the column 0-53 m (green), net "chemical flux" according to Reactions (R1) to (R3) (blue), $\mathrm{O}_{3}$ flux at the forest soil surface (brown), and $\mathrm{O}_{3}$ flux corrected for storage (black with IQR); Panels (e) and (f): $\mathrm{O}_{3}$ deposition velocity of storage-corrected flux.

\subsection{Influence of air humidity during the dry season}

Due to the fact that ozone deposition exhibits higher variability and limitations by the canopy resistance in the dry season, the latter is analyzed in more detail. To test the hypothesis that the physiological limitation of $\mathrm{O}_{3}$ deposition is related to high specific humidity deficit ( $S H D$ ) values, dry season measurements were classified on the basis of two specific humidity deficit categories, $S H D \leq 10 \mathrm{~g} \mathrm{~kg}^{-1}$ and $S H D>10 \mathrm{~g} \mathrm{~kg}^{-1}$. The critical value of $10 \mathrm{~g} \mathrm{~kg}^{-1}$ has been chosen according to the maximum average $S H D$ found in the wet season period (see Fig. 7). For both $S H D$ regimes, the median diel variations of deposition-related quantities are shown in Fig. 10.
The general course of the (storage corrected) $\mathrm{O}_{3}$ deposition flux shows a marked difference between both $S H D$ regimes during daytime. This difference is even more pronounced than the mean difference between the wet and dry season (see Fig. 8). While in the low SHD regime the diel course is quasi-symmetric and resembles the wet season results, it shows a clearly asymmetric shape in the high $S H D$ regime with very low values in the morning hours and maxima in the afternoon and the early night. This shape is in sharp contrast to the measured flux above the canopy that exhibits maximum values in the morning. Consequently, a large positive storage effect occurs in the morning and a negative one in the early night. For the two $S H D$ regimes, 

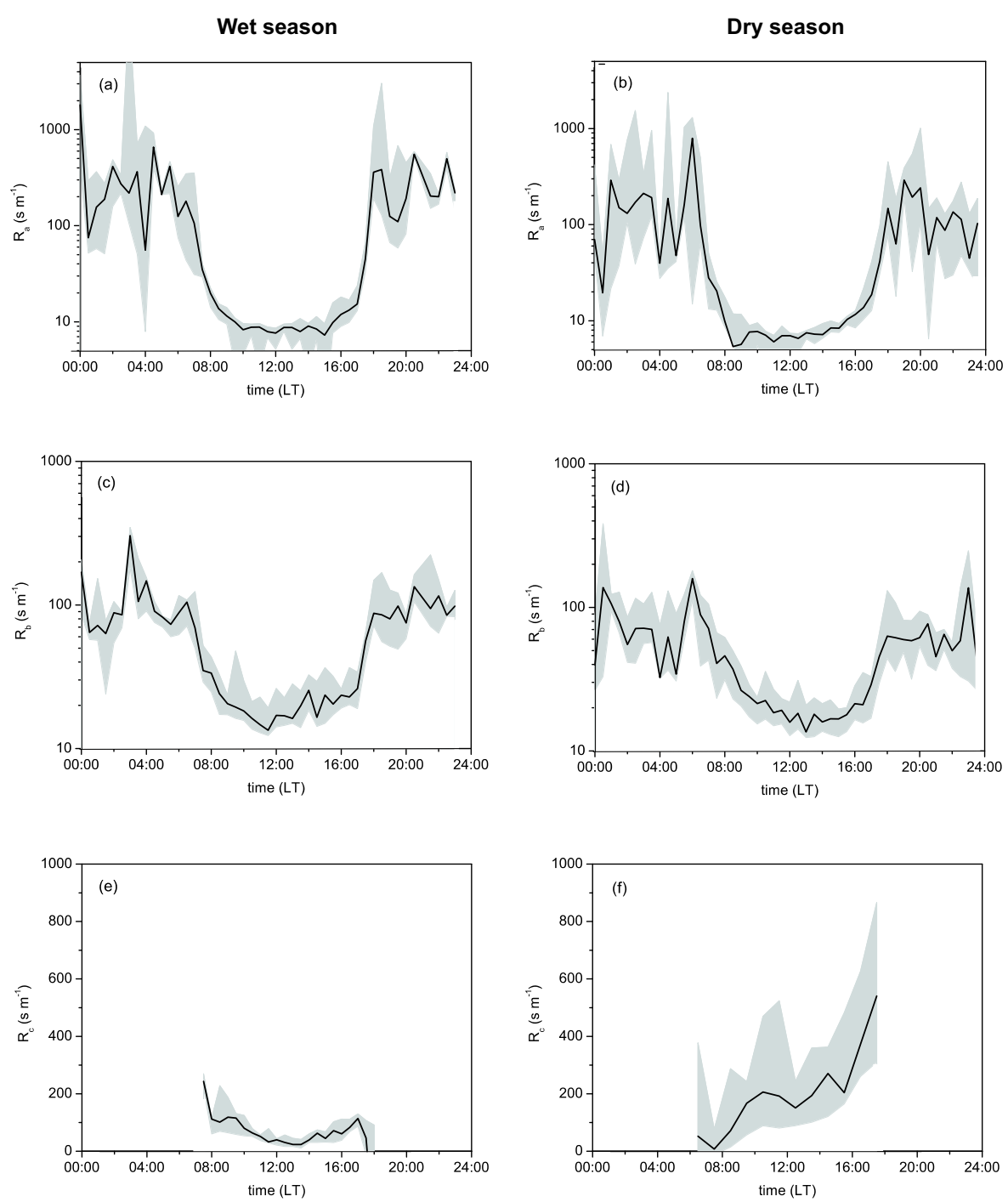

Fig. 9. Diel variation of mean (median) turbulent aerodynamic $\left(R_{a}\right)$, quasi laminar boundary layer $\left(R_{b}\right)$, and bulk canopy resistance $\left(R_{c}\right)$ at the RBJ tower during the wet season experiment (left panels) and the dry season experiment (right panels); corresponding inter quartile ranges are indicated by the gray shaded areas.

the resulting mean values of $v_{d}$ for daytime conditions are $0.8 \mathrm{~cm} \mathrm{~s}^{-1}$ and $0.3 \mathrm{~cm} \mathrm{~s}^{-1}$, respectively. The bulk surface resistance $R_{c}$ and the modeled stomatal resistance $R_{s, \mathrm{O}_{3}}$ (Eq. 6) agree well during most daytime hours in the case of the low $S H D$ regime (Fig. 10c). For the high $S H D$ regime, larger deviations with clearly higher $R_{c}$ than $R_{S, \mathrm{O}_{3}}$ values are observed especially before noon (Fig. 10d). In the afternoon a significant increase of the stomatal resistance is observed and $R_{c}$ and $R_{S, \mathrm{O}_{3}}$ show only minor differences.

\section{Discussion}

5.1 Difference between measured flux and actual deposition

According to Eq. (1) the $\mathrm{O}_{3}$ flux measured above the canopy has to be corrected for the storage change below the measurement height in order to determine the actual $\mathrm{O}_{3}$ deposition for a given time of day. This is particularly important for the quantitative study of daytime and nighttime deposition mechanisms (Sect. 5.3), and for the comparison of $\mathrm{O}_{3}$ deposition between forest and pasture vegetation (Sect. 5.4). However, for the comparison with other (airborne) studies over tropical rain forest (Sect. 5.2), which did not consider any storage effect, non-corrected fluxes and corresponding deposition velocities are also of interest. 

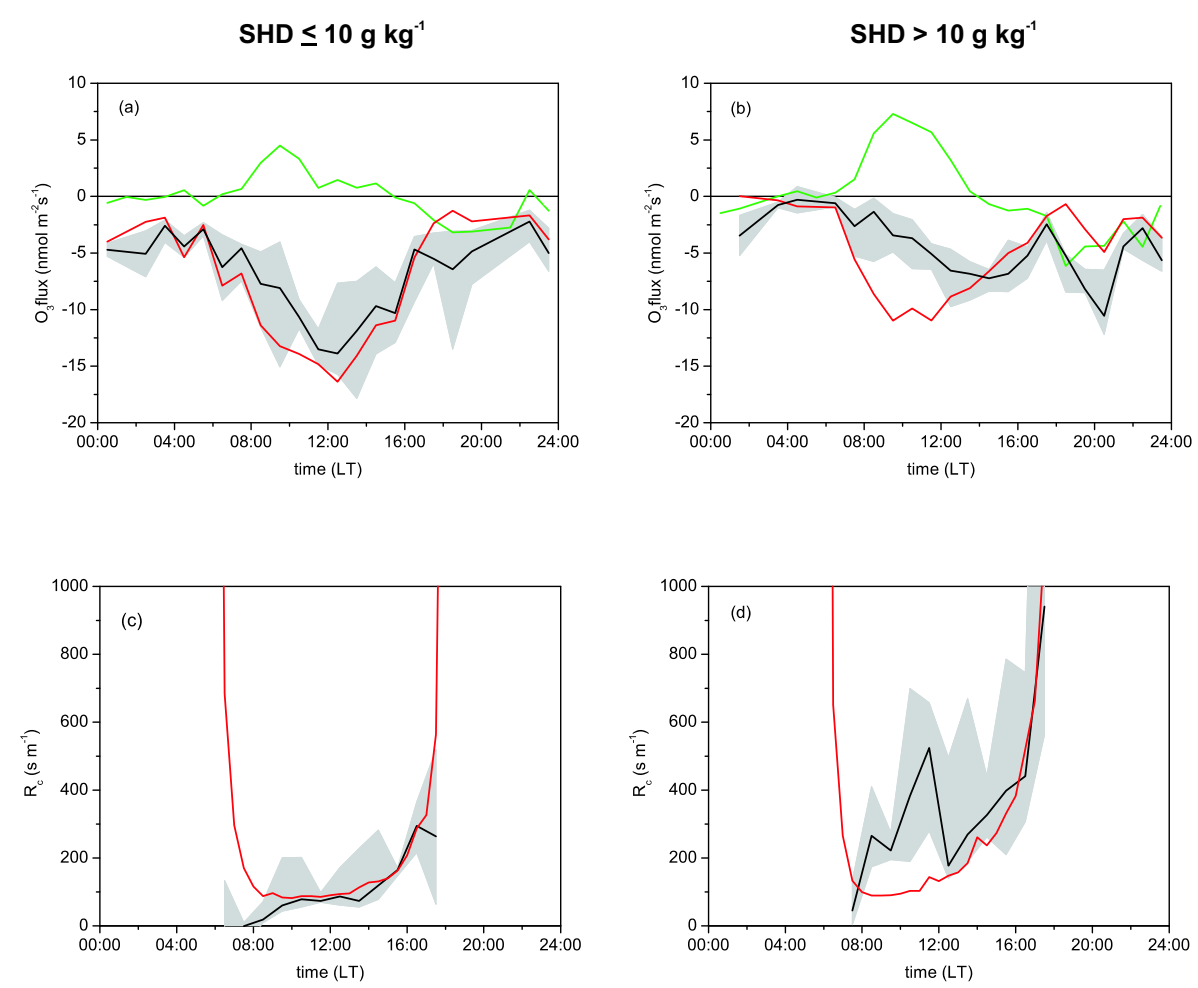

Fig. 10. Diel variation of ozone deposition related quantities (medians) during the dry season experiment separated for average daytime $S H D \leq 10 \mathrm{~g} \mathrm{~kg}^{-1}$ (left panels) and $S H D>10 \mathrm{~g} \mathrm{~kg}^{-1}$ (right panels). Panels (a) and (b): measured $\mathrm{O}_{3}$ flux at $53 \mathrm{~m}$ on the RBJ tower (red), $\mathrm{O}_{3}$ storage change within the column $0-53 \mathrm{~m}$ (green), storage corrected $\mathrm{O}_{3}$ deposition flux (black; with shaded inter quartile range); Panels (c) and (d): bulk canopy resistance $R_{C}$ (black; with shaded inter quartile range), and modeled stomatal resistance $R_{S}, \mathrm{O}_{3}$ (red).

Generally, the ozone storage change effect in the canopy layer and the layer immediately above is determined by the total diel amplitude (daytime maximum - nighttime minimum) of the ambient ozone mixing ratio. It was found to be four times higher in the dry than in the wet season (Fig. 5d). In addition, the daytime maximum $\mathrm{O}_{3}$ mixing ratio in the dry season also penetrated deeper into the canopy (Figs. 8a and b). Accordingly, during the wet season period, the storage change correction was rather small and had little effect on the more or less symmetric behavior of the measured $\mathrm{O}_{3}$ flux (Fig. 8c). This is in accordance with the wet season measurements over the rain forest in central Amazonia by Fan et al. (1990), where the diel variation of the mean $\mathrm{O}_{3}$ flux was also hardly affected by any storage correction (yet with only half the daytime $\mathrm{O}_{3}$ mixing ratios compared to RBJ). However, during the dry season experimental period (see Fig. 8d) the storage term was considerably enhanced due to the large diel variation of the ambient $\mathrm{O}_{3}$ mixing ratio.

The diel cycle of the storage term depends in detail on when and how fast the $\mathrm{O}_{3}$ mixing ratio changed with time. Shortly after sunrise, a massive increase of the $\mathrm{O}_{3}$ mixing ratio was observed during both measurement campaigns (Figs. 8a and b), somewhat more pronounced for the dry season period. It implies a considerable downward flux of $\mathrm{O}_{3}$ from higher layers into the near-surface layer. This $\mathrm{O}_{3}$ input is considered to be due to the breakdown of the large $\mathrm{O}_{3}$ gradients (see Gregory et al., 1988) between the ozone depleted nocturnal boundary layer (NBL) and the so-called residual layer (starting a few tens to hundreds of meters above the canopy top, with high $\mathrm{O}_{3}$ mixing ratios) caused by thermally driven turbulent mixing which starts shortly after sunrise. The decrease of ozone after sunset (18:00 LT) is almost as pronounced as the morning increase. At that time of day the surface layer over the forest canopy starts to stabilize with the establishment of the NBL (Nobre et al., 1996). During the night, the NBL gets decoupled from the rest of the mixing layer preventing the further supply of $\mathrm{O}_{3}$ from above. Furthermore, the NBL itself is usually not well mixed (weak turbulence due to low windspeeds and stable stratification) and the near surface layers get depleted of ozone by deposition and chemical reactions. Thus the speed of the evening $\mathrm{O}_{3}$ decrease depends on the stability of the NBL and on the sink strengths within the forest canopy (see Sect. 5.3).

The effect of the storage correction on the diel course of the $\mathrm{O}_{3}$ flux was significantly different between the two dry season $S H D$ regimes (Fig. 10). For low $S H D$ cases, the relatively symmetric course of the measured flux was hardly changed by the storage correction, and a similar behavior is generally found in the wet season (Fig. 8c). During periods of high $S H D$, the early maximum (Fig. 10b, 10:00 LT) of 
the measured $\mathrm{O}_{3}$ flux was shifted towards the afternoon (Fig. 10b, 15:00 LT) by the storage correction leading to a totally different asymmetric shape of the resulting diel deposition flux.

Summarizing, during the dry season (when biomass burning results in high ambient $\mathrm{O}_{3}$ mixing ratios) the storage change effect is of similar magnitude to the measured $\mathrm{O}_{3}$ flux. The $\mathrm{O}_{3}$ storage change correction altered the magnitude as well as the diel variation of the measured $\mathrm{O}_{3}$ flux. This finding is very similar to what has been reported for the $\mathrm{CO}_{2}$ exchange over the Brazilian rainforest during earlier experiments (see e.g. Grace, 1995; Malhi et al., 1998). Measured $\mathrm{CO}_{2}$ fluxes had to be substantially corrected for $\mathrm{CO}_{2}$ storage change to permit an appropriate analysis of $\mathrm{CO}_{2}$ source/sink mechanisms needed for interpretation and modeling purposes. Since previous dry season $\mathrm{O}_{3}$ studies in the tropics (see Table 1) did not consider the $\mathrm{O}_{3}$ storage change term and only a small influence from it was reported for temperate forests (e.g. Lamaud et al., 2002; Munger et al., 1996), our dry season results represent the highest ozone storage effects in forest deposition experiments reported so far.

\subsection{Mean deposition velocities and fluxes}

Table 1 gives a survey of mean fluxes and deposition velocities determined in this study together with results for tropical rain forest reported in the literature. The corresponding experiments took place in Amazonia and Equatorial Africa. For comparison purposes, mean (median) values for LBAEUSTACH 1 and 2 were calculated for the same diel intervals as used in those studies. When comparing results of different sites and experiments, the $\mathrm{O}_{3}$ deposition velocity, $v_{d}$, is generally more meaningful (representative) than the $\mathrm{O}_{3}$ flux, because it is normalized for the different ambient ozone mixing ratios. But, it has to be considered that $v_{d}$ is generally defined for a certain measurement height of flux and mixing ratio that might differ between the studies. This effect is not very important for daytime conditions when the boundary layer is relatively well mixed and the vertical mixing ratio gradients are small. However, during the night the relative vertical mixing ratio gradients usually become large, and then only rough comparisons of deposition velocities (and also fluxes) between different studies are possible. This problem is enhanced by the generally high uncertainty of nighttime deposition velocities representing the ratio of small and error-prone fluxes and mixing ratios.

There is only one other eddy covariance $\mathrm{O}_{3}$ flux experiment at a tower site above a tropical rain forest canopy, which was performed by Fan et al. (1990) during the wet season for 17 days in central Amazonia (Reserva Ducke, near Manaus). Their mean daytime deposition velocity of $1.8 \mathrm{~cm} \mathrm{~s}^{-1}$ was considerably higher than the $1.1 \mathrm{~cm} \mathrm{~s}^{-1}$ obtained at RBJ during the wet season experiment. But, with approximately two times lower mixing ratios at Reserva Ducke, the mean daytime flux was somewhat lower than at RBJ (see Table 1).
The nighttime $\mathrm{O}_{3}$ fluxes are almost identical for both sites. The corresponding $\mathrm{O}_{3}$ deposition velocities of $0.26 \mathrm{~cm} \mathrm{~s}^{-1}$ (Ducke) and $0.45 \mathrm{~cm} \mathrm{~s}^{-1}$ (RBJ) are much lower than the daytime values and show a larger difference, which may, however, be considered as hardly significant in view of the already mentioned uncertainty of nocturnal $v_{d}$ at low $\mathrm{O}_{3}$ mixing ratios.

For the tropical dry season, there are no direct towerbased flux measurements (eddy covariance) reported so far. The majority of available experimental results is based on airborne measurements. Very high mean $\mathrm{O}_{3}$ deposition fluxes of about $-27 \mathrm{nmol} \mathrm{m}^{-2} \mathrm{~s}^{-1}$ and $-40 \mathrm{nmol} \mathrm{m}^{-2} \mathrm{~s}^{-1}$ have been determined for central Amazonia with boundary layer budget approaches (Gregory et al., 1988; Kirchhoff et al., 1988). Gregory et al. (1988), whose $\mathrm{O}_{3}$ profiles were obtained by aircraft measurements, assess their estimate as a lower limit for the deposition flux, because possible boundary layer $\mathrm{O}_{3}$ sources have not been considered in their budget calculations. However, as stated by the authors, their mean deposition velocity of $\sim 5 \mathrm{~cm} \mathrm{~s}^{-1}$ seems to be unrealistically high. The huge $\mathrm{O}_{3}$ fluxes reported by Kirchhoff et al. (1988) probably imply a similarly high deposition velocity.

Ozone deposition fluxes measured above tropical forests in central Africa, mainly in Congo, are somewhat lower. An average $\mathrm{O}_{3}$ flux of $-15 \mathrm{nmol} \mathrm{m}^{-2} \mathrm{~s}^{-1}$ was obtained for early morning situations by Cros et al. (1992), using a budget approach on the basis of vertical $\mathrm{O}_{3}$ profiles from tethered balloon measurements. But the reported large variability of the estimates together with the rather high deposition velocities of $\sim 5 \mathrm{~cm} \mathrm{~s}^{-1}$ make the results questionable. During a later experiment, Cros et al. (2000) obtained $\mathrm{O}_{3}$ fluxes of similar magnitude, around $-14 \mathrm{nmol} \mathrm{m}^{-2} \mathrm{~s}^{-1}$, during the morning hours by direct airborne eddy covariance measurements and by an atmospheric boundary layer budget approach. Based on corresponding $\mathrm{O}_{3}$ mixing ratios, they determined a mean deposition velocity of about $1.5 \mathrm{~cm} \mathrm{~s}^{-1}$. These values are considerably higher than the mean $\mathrm{O}_{3}$ flux and deposition velocity observed during the dry season experiment at the RBJ tower ( $-7.7 \mathrm{nmol} \mathrm{m}^{-2} \mathrm{~s}^{-1}$ and $0.6 \mathrm{~cm} \mathrm{~s}^{-1}$, respectively) for a comparable time interval (08:00 LT to 13:00 LT). But the airborne methods have not taken into account the storage change within and just above the forest, which was found to be large at RBJ especially in the morning hours (Table 1). Moreover, it has to be considered that the measurements in Congo have been performed at the beginning of the local dry season. Probably due to that reason, they agree much better with the results of LBA-EUSTACH 1 (end of the wet season) with a mean $\mathrm{O}_{3}$ deposition velocity of $1.4 \mathrm{~cm} \mathrm{~s}^{-1}\left(1.5 \mathrm{~cm} \mathrm{~s}^{-1}\right.$ without storage correction) between 08:00 LT and 13:00 LT. It can be stated that the mean daytime $\mathrm{O}_{3}$ deposition velocity of $0.5 \mathrm{~cm} \mathrm{~s}^{-1}$ obtained for the dry season experiment at RBJ is much lower than any results reported in previous tropical rain forest studies. 
However, it is comparable to findings above temperate forests during summer (daytime means of about $0.4 \mathrm{~cm} \mathrm{~s}^{-1}$ by Lamaud et al., 2002; and about $0.6 \mathrm{~cm} \mathrm{~s}^{-1}$ by Munger et al., 1996) and recent results of Matsuda et al. (2005) from a partly leafless tropical savanna teak forest during the dry season in northern Thailand (ca. $0.4 \mathrm{~cm} \mathrm{~s}^{-1}$ ).

Nocturnal $\mathrm{O}_{3}$ deposition over the Congo forest at the end of dry season was determined by Andreae et al. (1992) by a budget approach using aircraft $\mathrm{O}_{3}$ profile measurements. They estimated a mean $\mathrm{O}_{3}$ deposition flux and velocity of $-2.5 \mathrm{nmol} \mathrm{m}^{-2} \mathrm{~s}^{-1}$ and $1.2 \mathrm{~cm} \mathrm{~s}^{-1}$. Corresponding values at RBJ during the dry season experiment are $-2.4 \mathrm{nmol} \mathrm{m}^{-2} \mathrm{~s}^{-1}$ and $0.4 \mathrm{~cm} \mathrm{~s}^{-1}$ (without storage correction for better comparability with aircraft measurements). While the $\mathrm{O}_{3}$ fluxes agree quite well, deposition velocities differ by a factor of three.

\subsection{Ozone deposition mechanisms}

The mean diel course of the deposition velocity $v_{d}$, (Figs. 8e, f) and the bulk canopy resistance $R_{c}$ (Figs. 9e, f) exhibit a clear seasonal difference during daytime. For the wet season period, $R_{c}$ shows a symmetrical form of the diel variation analogous to the $\mathrm{O}_{3}$ deposition flux. The daytime mean value of $R_{c}=55 \mathrm{~s} \mathrm{~m}^{-1}$ is not much larger than the corresponding sum of $R_{a}+R_{b}$. Thus, the forest canopy represents a highly effective sink for ozone in the wet season. In contrast, daytime mean $R_{c}$ during the dry (burning) season experiment was about three times higher than in May, to a large part as a response to the higher $S H D$, as demonstrated in Fig. 10. Similar values of the modeled bulk stomatal resistance $R_{s, \mathrm{O}_{3}}$ indicate that daytime $\mathrm{O}_{3}$ deposition is mainly controlled and almost fully explained by stomatal uptake. Also the highly asymmetric course of $R_{c}$ in the dry season with lowest values in the morning and a distinct increase during the day can be attributed to the limiting effect of $S H D$ showing similar diurnal behavior (Fig. 5c), which is in accordance with the porometer-based measurements of McWilliam et al. (1996), who found a clear dependence of canopy stomatal resistance on $S H D$ with a similar diurnal course at the RBJ site.

In the high $S H D$ regime (Fig. 10d) with generally increased resistances, clearly higher $R_{c}$ than $R_{s, \mathrm{O}_{3}}$ values are observed before noon. Two different explanations might be possible. The storage correction of the measured $\mathrm{O}_{3}$ flux might be overestimated due to horizontal advective contributions to the $\mathrm{O}_{3}$ budget, which are not considered in Eq. (1). Particularly during periods of high biomass burning, such an influence can not be ruled out, although no systematic effect of wind direction has been found. Another possibility to explain the differences between $R_{c}$ and $R_{S}, \mathrm{O}_{3}$ may be the inadequate consideration of the developmental state of the canopy in the stomatal resistance model of Wright et al. (1996) (see Sect. 3.3). Shortly before and during our experiment at the end of the dry season, most deciduous tree species shed senescent foliage and developed fresh leaves.
Rottenberger et al. (2005) investigated the physiology of the local tree species Hymenaea courbaril L. at RBJ as a function of the developmental state and found that at the begin of October significantly higher stomatal resistances occurred at senescent as well as fresh leaves compared to already matured foliage towards the end of the month. There is only a weak consideration of the late dry season period in the model calibration by Wright et al. (1996), and thus their parameterization is probably dominated by the physiological behavior of mature foliage.

The observed regular exposure of the tropical trees to very high $\mathrm{O}_{3}$ mixing ratios ( $>50 \mathrm{ppb}$, afternoon) might cause permanent plant damage. In a greenhouse experiment by Gut et al. (2002b) young tropical tree species showed substantial leaf damage (S. Rottenberger, personal communication) after a few days of $\mathrm{O}_{3}$ fumigation (daytime maximum values of $\sim 60 \mathrm{ppb}$ ). On the other hand, it was recognized, e.g. by Fuhrer et al. (1992), that the impact on plants might be more closely related to the internal $\mathrm{O}_{3}$ dose or the flux of $\mathrm{O}_{3}$ through the stomata than to the exposure to high ambient $\mathrm{O}_{3}$ mixing ratios. As the $\mathrm{O}_{3}$ flux at $\mathrm{RBJ}$ was found to be reduced during periods of extreme $\mathrm{O}_{3}$ mixing ratios (due to simultaneously occurring high specific humidity values), adverse consequences for the forest might be limited.

During the dry season campaign the mean nocturnal flux was about $60 \%$ of the corresponding daytime flux (see Table 1). Under the assumption that leaf stomata are closed during the night, the ozone deposition must be explained by other removal mechanisms in the forest canopy that may have been masked during daytime by the dominant stomatal uptake. Possible pathways are (i) the deposition to the ground surface and (ii) to outer plant surfaces (leaves' cuticles, bark) as well as (iii) the chemical loss due to reaction with NO (Reaction R3). The first mechanism was quantified by Gut et al. (2002b) and is included in Figs. 8c and d. Its effect is very small during both seasons and does not significantly contribute to the observed nighttime deposition.

The contribution of the $\mathrm{NO}_{\mathrm{x}}$-chemistry to the ozone budget as calculated from the respective concentration profiles is also displayed in Fig. 8. During nighttime, in the dry season, it represents a considerable, relatively constant sink of the order of $2 \mathrm{nmol} \mathrm{m}^{-2} \mathrm{~s}^{-1}$. This is much higher than the mean NO soil emission of 0.3 to $0.4 \mathrm{nmol} \mathrm{m}^{-2} \mathrm{~s}^{-1}$ obtained by Gut et al. (2002a) and Rummel et al. (2002) via direct flux measuring techniques (dynamic soil chamber and eddy covariance) for that period. Most likely, NO-rich air originating from biomass burning and advected within the stable nocturnal boundary layer is contributing significantly to the chemical $\mathrm{O}_{3}$ sink at night. Between midnight and sunrise this can explain the major part of the observed flux. In combination with the continuously decreasing ambient $\mathrm{O}_{3}$ mixing ratio (Fig. 8b) it may also explain the peak in the deposition velocity around 04:00 LT. Yet the high uncertainty under these conditions, and a reduced data coverage due to rigorous application of rejection criteria (Sect. 3.1) have to 
be taken into account.

During the first half of the night, the ozone deposition flux is $\mathbf{2}-\mathbf{5}$ times higher than the chemical sink, also as a result of the large storage change effect. After sunset, the high evening $\mathrm{O}_{3}$ mixing ratios of the dry season experiment were rapidly depleted indicating another effective ozone removal mechanism besides the chemical loss reaction with NO. Andreae et al. (1992) came to a similar result for their early night experiment in the Congo (see Table 1). They estimated the chemical contribution to $\mathrm{O}_{3}$ deposition as only about $35 \%$ by assuming the relatively high NO dry season soil emissions measured by Kaplan et al. (1988) in central Amazonia. In both cases, a significant additional sink is necessary to close the early night ozone budget. A possible process is deposition to the leaf cuticles (outer surfaces). For the present study, there is no independent quantitative information about this mechanism. Taking the typical residual (non-explained) part of the deposition velocity during early night of the dry season in the order of $0.4 \mathrm{~cm} \mathrm{~s}^{-1}$, the corresponding bulk surface resistance must be as low as $250 \mathrm{~s} \mathrm{~m}^{-1}$. This value is not very plausible for a cuticular resistance during daytime, since it is comparable to the daytime bulk stomatal resistance and the latter already explains the observed $\mathrm{O}_{3}$ deposition to a satisfying degree. However, Zhang et al. (2002) and Altimir et al. (2006) found for forest and other ecosystems that the nonstomatal canopy resistance (attributed mainly to cuticular deposition) strongly depends on relative humidity and surface wetness. For high values of relative humidity (above 70 $80 \%$ ), often observed during nighttime, they report strongly decreasing canopy resistance values comparable in magnitude to our results. Therefore, we attribute the considerable nocturnal ozone deposition, which is not explained by chemical reactions, to uptake by the leaf surfaces. Yet, a disturbing influence of errors in the nocturnal flux measurements, or of deviations from the ideal assumptions of the ozone budget (e.g. advection effects as mentioned above) cannot be completely excluded.

\subsection{Deforestation impact on ozone deposition}

Since total ozone deposition to a vegetated surface is largely controlled by plant physiological mechanisms, any (large scale) change in land-use is expected to result in a change of ozone deposition and may thus affect regional $\mathrm{O}_{3}$ budgets. This might particularly be the case for the Brazilian state of Rondônia, where large areas of primary rain forest are continuously deforested and subsequent development to cattle pastures takes place (cf. Kirkman et al., 2002). The average deforestation rate in central Rondônia increased between 1990 and 1999 from $\sim 1.2 \%$ per year to $\sim 3.4 \%$ per year (Roberts et al., 2002). The LBA-EUSTACH 1 and 2 experiments offered the unique possibility to establish a direct and comprehensive comparison of $\mathrm{O}_{3}$ uptake by pasture and rain forest, since Kirkman et al. (2002) measured $\mathrm{O}_{3}$ deposition at a cattle pasture site simultaneously to the forest work during both campaigns, using a combination of soil chamber and micrometeorological profile techniques. As shown in Fig. 1, the pasture site Fazenda Nossa Senhora (FNS) is only about $60 \mathrm{~km}$ southwest of the RBJ forest site and thus experiences the same seasonality and similar weather conditions. In order to make the data of Kirkman et al. comparable to the results of our study, they have been subjected to a reevaluation using equivalent rejection criteria as described in Sect. 3.1.

Figure 11 displays the diel variations of median $\mathrm{O}_{3}$ mixing ratios, fluxes, and deposition velocities at both sites and for both seasons. It shows that the ambient $\mathrm{O}_{3}$ mixing ratios at both sites were very similar during daylight hours. Overall seasonal mean values, based on the 24 individual hourly means, and the resulting percentage of $\mathrm{O}_{3}$ deposition to pasture (FNS) compared to forest (RBJ) are listed in Table 2. For comparing total ozone deposition, the arithmetic average is the most reasonable quantity, since it represents an integral measure. For deposition velocities, however, a $24 \mathrm{~h}$ mean is not very meaningful due to the distinct diel course of the ozone mixing ratio and the uncertainty of nighttime data. Therefore, in accordance with the results in Table 1, daytime median values for $v_{d}$ are shown.

The total $\mathrm{O}_{3}$ flux to the grass pasture site was found to be $70 \%$ of the flux obtained for the RBJ rain forest during the wet season experiment (May). As shown in Fig. 11a, the main part of this $\mathrm{O}_{3}$ flux difference originates from daytime hours. Because of the similar ozone mixing ratios of the neighboring sites, the ratio of daytime deposition velocities shows, with $58 \%$, a slightly lower but comparable value. Consequently, the difference between pasture and forest is mainly explained by the daytime bulk canopy resistances. The mean $R_{c}$ of the forest canopy is about $55 \mathrm{~s} \mathrm{~m}^{-1}$ during daytime (see Sect. 4.3), only half of the mean $R_{C}$ of the pasture canopy of $100 \mathrm{~s} \mathrm{~m}^{-1}$ (Kirkman et al., 2002).

During the dry season campaign, there is a different picture. The $\mathrm{O}_{3}$ flux ratio between the FNS pasture and RBJ forest is $82 \%$, somewhat larger than during the wet season experiment. However, the corresponding ratio of daytime $v_{d}$ is about $100 \%$. Figure $11 \mathrm{~b}$ shows that for the $\mathrm{O}_{3}$ flux during daytime there are no significant differences between the two ecosystems. This indicates a very different seasonal variation of $R_{c}$ at both sites. Whereas the mean $R_{c}$ for the RBJ primary rain forest during September-October was three times higher than in May (see Sect. 4.3), no significant difference in $R_{c}$ was found between both seasons for the FNS pasture (Kirkman et al., 2002). This is most likely a consequence of a weaker response of $R_{c}$ at FNS to specific humidity deficits $(S H D)$ and is in accordance with the porometer-based measurements of McWilliam et al. (1996). They found no significant dependence of the stomatal resistance at FNS on SHD, in contrast to a clear dependence of canopy stomatal resistance on $S H D$ at the RBJ site. Moreover, since the grass canopy at FNS exhibited also considerable gaps exposing bare soil patches, probably a large fraction of $\mathrm{O}_{3}$ deposition 
Table 2. Comparison of average ozone flux ( $\mathrm{nmol} \mathrm{m}^{-2} \mathrm{~s}^{-1}$ ) and daytime median deposition velocity ( $\mathrm{cm} \mathrm{s}^{-1}$ ) measured at Rebio Jaru (RBJ) and Fazenda Nossa Senhora Aparecida (FNS) during both LBA-EUSTACH experiments. "Ratio" is the percentage of the corresponding pasture to forest values. Also listed are the average values and corresponding ratios based on the results of Sigler et al. (2002). "RD" is the Reserva Ducke rain forest site in central Amazonia $\left(2^{\circ} 57^{\prime} \mathrm{S}, 59^{\circ} 57^{\prime} \mathrm{W}\right)$.

\begin{tabular}{|c|c|c|c|c|c|c|}
\hline Data Source & Season & Site & flux $(24 h)^{d}$ & Ratio & $v_{d}(\text { day })^{\mathrm{e}}$ & Ratio \\
\hline \multirow{2}{*}{$\begin{array}{l}\text { LBA-EUSTACH } \\
\text { (this study and Kirkman et al., 2002) }\end{array}$} & Wet & $\begin{array}{l}\text { RBJ } \\
\text { FNS }\end{array}$ & $\begin{array}{l}-2.93 \\
-2.04\end{array}$ & $70 \%$ & $\begin{array}{l}1.2 \\
0.7\end{array}$ & $58 \%$ \\
\hline & Dry & $\begin{array}{l}\text { RBJ } \\
\text { FNS }\end{array}$ & $\begin{array}{l}-5.69 \\
-4.68\end{array}$ & $82 \%$ & $\begin{array}{l}0.6 \\
0.6\end{array}$ & $100 \%$ \\
\hline $\begin{array}{l}\text { ABLE } 2 B^{b} \text { (Fan et al., 1990) } \\
\text { LBA-TRMM }^{\mathrm{c}} \text { (Sigler et al., 2002) }\end{array}$ & Wet & $\begin{array}{c}\text { RD } \\
\text { FNS }\end{array}$ & $\begin{array}{l}-1.82 \\
-1.55\end{array}$ & $85 \%$ & $\begin{array}{l}1.6 \\
0.5\end{array}$ & $31 \%$ \\
\hline
\end{tabular}

a LBA-EUSTACH 1 data periods: 4 to 22 May 1999 (RBJ), 1 to 17 May 1999 (FNS). LBA-EUSTACH 2 data periods: 21 September to 20 October 1999 (RBJ), 24 September to 20 October 1999 (FNS).

b RD data from ABLE 2B experiment 22 April to 8 May 1987.

${ }^{\mathrm{c}}$ FNS data from LBA-TRMM experiment January/February 1999.

$\mathrm{d}$ Overall averages of hourly means.

e Medians of daytime hourly means.
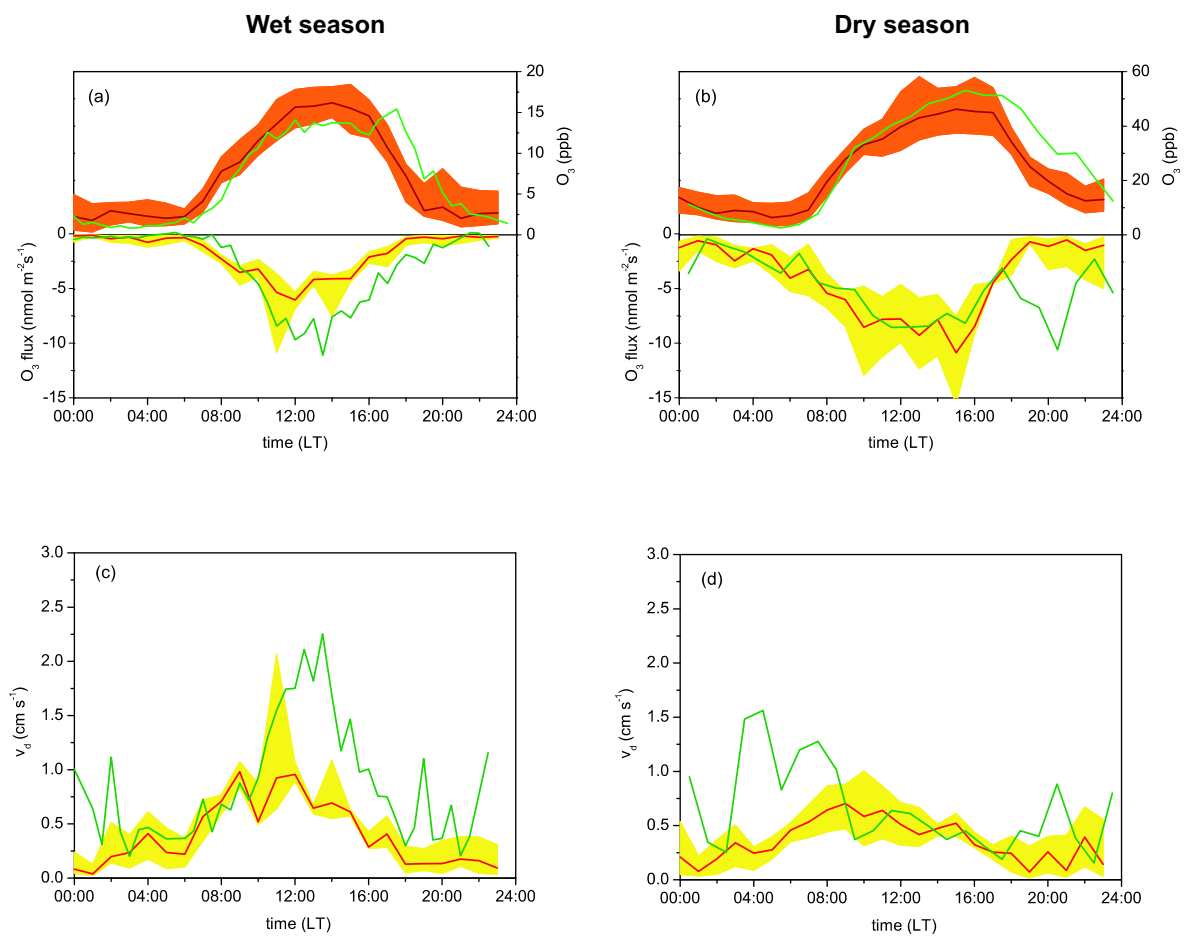

Fig. 11. Mean (median) diel variation of quantities related to ozone deposition at the FNS pasture and RBJ forest sites during the wet season experiment (left panels) and the dry season experiment (right panels). Panels (a) and (b): $\mathrm{O}_{3}$ mixing ratio at FNS (brown) and RBJ (green), storage corrected deposition flux at FNS (red) and RBJ (dark green); Panels (c) and (d): deposition velocity at FNS (red) and RBJ (dark green). Orange and yellow shaded areas represent interquartile ranges for the FNS results.

was due to direct deposition to bare soil surfaces. The main contribution to the difference in total $\mathrm{O}_{3}$ deposition between RBJ and FNS during the dry season experiment originates from the nighttime observations, mainly as a consequence of (i) higher NO soil emission (Gut et al., 2002a; Kirkman et al.,
2002), (ii) higher aerodynamic surface roughness, and (iii) a larger LAI (i.e. non-stomatal uptake) at the RBJ forest site. Considerably larger $\mathrm{O}_{3}$ fluxes at RBJ (Fig. 11b) occur during the first half of the night in accordance with the higher $\mathrm{O}_{3}$ mixing ratios compared to FNS during that time of day. 
A previous estimate of contrasting $\mathrm{O}_{3}$ uptake by pasture and rain forest was made by Sigler et al. (2002) for wet season conditions only. They report $\mathrm{O}_{3}$ fluxes from the same pasture site (FNS), but measured in January and February 1999, and compared them to the wet season results for a primary rain forest in central Amazonia (Reserva Ducke; RD) obtained 12 years earlier (Fan et al., 1990). To make their results comparable to ours, we re-evaluated the data in Fig. 6 of Sigler et al. to obtain overall average fluxes and daytime median deposition velocities (also listed in Table 2). The resulting $\mathrm{O}_{3}$ flux ratio of FNS over $\mathrm{RD}$ is $85 \%$, which is somewhat larger than the corresponding ratio (70\%) of FNS over RBJ during the wet season campaign. However, the ratio of $\mathrm{O}_{3}$ deposition velocities given by Sigler et al. is much smaller $(31 \%)$. In contrast to very comparable daytime $\mathrm{O}_{3}$ mixing ratios at FNS and RBJ during the wet season campaign, the daytime $\mathrm{O}_{3}$ mixing ratios measured by Sigler et al. at FNS were 2-3 times higher than those at $\mathrm{RD}$ during the time period considered, making their forest-pasture comparison questionable. They argued that the different mixing ratios were due to (inherently) different ozone production regimes due to different precursor emissions above forest and pasture vegetation. In contrast, the results of the LBA-EUSTACH campaigns demonstrate that daytime ozone mixing ratios at the FNS site are not significantly different from comparable forested areas.

\section{Conclusions}

The continuous ozone flux measurements during the wet and dry season campaigns of LBA-EUSTACH at the rain forest site RBJ exhibited distinct differences in the magnitude and diel variation of $\mathrm{O}_{3}$ flux and $\mathrm{O}_{3}$ deposition velocity. The results of the wet season experiment were comparable to previous findings by Fan et al. (1990), showing only minor limitations by the generally small canopy resistances. In contrast, the results of the dry (burning) season experiment showed strong limitation of daytime $\mathrm{O}_{3}$ deposition most likely controlled by plant physiological processes (stomatal aperture) as a response to large values of the specific humidity deficit. This result has to be considered as unique, since to our knowledge, there were no data available to date about diel variation and mechanisms of $\mathrm{O}_{3}$ deposition to tropical rain forests during the dry season. The high ozone concentrations at the end of the dry season, as a consequence of strong regional biomass burning activities, resulted in large daytime ozone mixing ratios that also caused a substantial canopy storage of $\mathrm{O}_{3}$, which changed and masked the true diel variation of ozone deposition in the measured eddy covariance flux. Since the surface deposition represents the major sink for boundary layer ozone, the occurrence of very high mixing ratios up to $80 \mathrm{ppb}$ during the burning season was also favored by the reduced daytime $\mathrm{O}_{3}$ uptake capability.
The reduced $\mathrm{O}_{3}$ uptake during the dry season was also visible in the comparison between $\mathrm{O}_{3}$ deposition to cattle pasture and to primary rain forest. As a result, the effect of forest-pasture conversion on ozone deposition is less during the dry season (pasture/forest flux ratio $=82 \%$ ) than during the wet season $(70 \%)$. Whether these reduction effects are representative for the whole of Amazonia depends on the physiological response of the different rain forest canopies, e.g. in central Amazonia, and on the seasonal variations of environmental conditions like $S H D$ and soil water availability.

Acknowledgements. This study was supported by the "Environmental and Climate Programme" (Project LBA-EUSTACH, ENV4-CT97-0566) of the European Union, and by the Max Planck Society. We would like to thank the staff at INCRA (Instituto Nacional de Colonização e Reforma Agrária), especially J. L. Esteves, E. Conceição, and C. Rodrigues. Further, C. Brãndao and the staff of IBAMA (Instituto Brasileiro do Meio Ambiente e dos Recursos Naturais Renováveis) in Ji-Paraná are gratefully acknowledged for their help in installing and maintaining the infrastructure at the forest. We are indebted to B. E. Gomes (Universidade Federal de Rondônia, Ji-Paraná) for support concerning everything and to A. Pereira de Andrade for allowing us to measure at his Fazenda Nossa Senhora Aparecida. We are also grateful to J. v. Jouanne, M. Scheibe, M. Welling, and W. Saores da Silva for assisting us in the field. Special thanks to H. P. Schmid for providing his footprint model and to T. W. Andreae for improving the language of the manuscript.

Disclaimer. The views expressed herein are those of the authors and do not necessarily reflect the views of the UNFCCC (United Nations Framework Convention on Climate Change).

Edited by: R. Cohen

\section{References}

Altimir, N., Kolari, P., Tuovinen, J.-P., Vesala, T., Bäck, J., Suni, T., Kulmala, M., and Hari, P.: Foliage surface ozone deposition: a role for surface moisture?, Biogeosciences, 3, 209-228, 2006, http://www.biogeosciences.net/3/209/2006/.

Ammann, C.: On the aplicability of relaxed eddy accumulation and common methods for measuring trace gas fluxes, Dissertation Thesis, Universität Zürich, available at: http://e-collection. ethbib.ethz.ch/cgibin/show.pl?type=diss\&nr=12795, 1999.

Andreae, M. O., Browell, E. V., Garstang, M., Gregory, G. L., Harriss, R. C., Hill, G. F., Jacob, D. J., Pereira, M. C., Sachse, G. W., Setzer, A. W., Silva Dias, P. L., Talbot, R. W., Torres, A. L., and Wofsy, S. C.: Biomass-burning emissions and associated haze layers over Amazonia, J. Geophys. Res., 93(D2), 1509-1527, 1988.

Andreae, M. O., Chapuis, A., Cros, B., Fontan, J., Helas, G., Justice, C., Kaufman, Y. J., Minga, A., and Nganga, D.: Ozone and Aitken nuclei over Equatorial Africa: Airborne observations during DECAFE 88, J. Geophys. Res., 97(D6), 6137-6148, 1992.

Andreae, M. O., Artaxo, P., Brandao, C., Carswell, F. E., Ciccioli, P., da Costa, A. L., Culf, A., Esteves, J. L., Gash, J. H. C., Grace, 
J., Kabat, P., Lelieveld, J., Mahli, Y., Manzi, A. O., Meixner, F. X., Nobre, A. D., Nobre, C., Ruivo, M. d. L. P., Silva-Dias, M. A., P., S., Valentini, R., von Jouanne, J., and Waterloo, M. J.: Biogeochemical cycling of carbon, water, energy, trace gases, and aerosols in Amazonia, J. Geophys. Res., 107(D20), 8066, doi:10.1029/2001JD000524, 2002.

Aubinet, M., Grelle, A., Ibrom, A., Rannik, U., Moncrieff, J. B., Foken, T., Kowalski, A. S., Martin, P. H., Berbigier, P., Bernhofer, C., Clement, R., Elbers, J., Granier, A., Grünwald, T., Morgenstern, K., Pilegaard, K., Rebmann, C., Snijders, W., Valentini, R., and Vesala, T.: Estimation of annual net carbon and water exchange of forests: The EUROFLUX methodology, Adv. Ecol. Res., 30, 113-175, 2000.

Baldocchi, D. D., Hicks, B. B., and Camara, P.: A canopy stomatalresistance model for gaseous deposition to vegetated surfaces, Atmos. Environ., 21(1), 91-101, 1987.

Beier, N. and Schneewind, R.: Chemical reactions of gases in tubes of probing systems and their influence on measured concentrations, Ann. Geophys., 9, 703-707, 1991,

http://www.ann-geophys.net/9/703/1991/.

Chameides, A. L., Fehsenfeld, F. C., Rodgers, M. O., Cardelino, C., Martinez, J., Parrish, D. D., Lonneman, W., Lawson, D. R., Rasmussen, R. A., Zimmermann, P., Greenberg, J., Middleton, P., and Wang, T.: Ozone precursor relationships in ambient atmosphere, J. Geophys. Res., 97(D5), 6037-6055, 1992.

Coppin, P. A., Raupach, M. R., and Legg, B. J.: Experiments on scalar dispersion within a model-plant canopy. 2. An elevated plane source, Bound.-Lay. Meteorol., 35(1-2), 167-191, 1986.

Cros, B., Delmas, R., Nganga, D., Clairac, B., and Fontan, J.: Seasonal trends of ozone in Equatorial Africa: experimental evidence of photochemical formation, J. Geophys. Res., 93(D7), 8355-8366, 1988.

Cros, B., Fontan, J., Minga, A., Helas, G., Nganga, D., Delmas, R., Chapuis, A., Benech, B., Druilhet, A., and Andreae, M. O.: Vertical profiles of ozone between 0 and 400 meters in and above the African Equatorial forest, J. Geophys. Res., 97(D12), $12877-$ $12887,1992$.

Cros, B., Delon, C., Affre, C., Marion, T., Druilhet, A., Perros, P. E., and Lopez, A.: Sources and sinks of ozone in savanna and forest areas during EXPRESSO: Airborne turbulent flux measurements, J. Geophys. Res., 105(D24), 29347-29358, 2000.

Crutzen, P. J.: The role of $\mathrm{NO}$ and $\mathrm{NO}_{2}$ in the chemistry of the troposphere and the stratosphere, Ann. Rev. Earth Planet. Sci., 7, 443-472, 1979.

Crutzen, P. J., Delany, A. C., Greenberg, J., Haagenson, P., Heidt, L., Lueb, R., Pollock, W., Seiler, W., Wartburg, A., and Zimmermann, P.: Tropospheric chemical composition measurements in Brazil during the dry season, J. Atmos. Chem., 2, 233-256, 1985.

Crutzen, P. J.: The role of the tropics in atmospheric chemistry, in The Geophysiology of Amazomia, edited by: Dickinson, R. E., pp. 107-130, John Wiley, New York, 1986.

Crutzen, P. J. and Andreae, M. O.: Biomass burning in the tropics: impact on atmospheric chemistry and biogeochemical cycles, Science, 250, 1669-1678, 1990.

Culf, A., Esteves, J. L., Marques Filho, A. d. O., and da Rocha, H. R.: Radiation, temperature and humidity over forest and pasture in Amazonia, in Amazonian deforestation and climate, edited by: Gash, J. H. C., Nobre, C. A., Roberts, J. M., and Victoria, R. L., pp. 175-191, John Wiley \& Sons, Chichester, 1996.
Delany, A. C., Haagenson, P., Walters, S., Wartburg, A., and Crutzen, P. J.: Photochemically produced ozone in the emission from large-scale tropical vegetation fires, J. Geophys. Res., 90(D1), 2425-2429, 1985.

Fan, S. M., Wofsy, S. C., Bakwin, P. S., Jacob, D. J., and Fitzjarrald, D. R.: Atmosphere-biosphere exchange of $\mathrm{CO}_{2}$ and $\mathrm{O}_{3}$ in the central Amazon forest, J. Geophys. Res., 95(D10), 16851$16864,1990$.

Foken, T. and Wichura, B.: Tools for quality assessment of surfacebased flux measurements, Agric. Forest Meteorol., 78, 83-105, 1996.

Fuhrer, J., Grandjean Grimm, A., Tschannen, W., and ShariatMadari, H.: The response of spring wheat (Triticum aestivum L.) to ozone at higher elevations. 2 Changes in yield, yield components and grain quality in response to ozone flux, New Phytol., 13, 459-464, 1992.

Gash, J. H. C., Nobre, J. M., Roberts, J. M., and Victoria, R. L.: An overview of ABRACOS, in Amazonian deforestation and climate, edited by: Gash, J. H. C., Nobre, J. M., Roberts, J. M., and Victoria, R. L., pp. 1-14, John Wiley \& Sons, Chichester, 1996.

Grace, J., Lloyd, J., McIntyre, J., Miranda, A. C., Meir, P., Miranda, H. S., Nobre, C., Moncrieff, J., Massheder, J., Malhi, Y., Wright, I., and Gash, J.: Carbon dioxide uptake by an undisturbed tropical rain forest in southwest Amazonia, 1992 to 1993, Science, 270, 778-780, 1995.

Gregory, G. L., Browell, E. V., and Warren, L. S.: Boundary-layer ozone - an airborne survey above the Amazon Basin, J. Geophys. Res., 93(D2), 1452-1468, 1988.

Gregory, G. L., Browell, E. V., and Warren, L. S.: Amazon Basin ozone and aerosol: Wet season observations, J. Geophys. Res., 95(D10), 16 903-16912, 1990.

Güsten, H., Heinrich, G., Schmidt, R. W. H., and Schurath, U.: A novel ozone sensor for direct eddy flux measurements, J. Atmos. Chem., 14, 73-84, 1992.

Güsten, H. and Heinrich, G.: On-line measurements of ozone surface fluxes: Part I. Methodology and instrumentation, Atmos. Environ., 30(6), 897-909, 1996.

Gut, A., van Dijk, S. M., Scheibe, M., Rummel, U., Welling, M., Ammann, C., Meixner, F. X., Andreae, M. O., and Lehmann, B. E.: NO emission from an Amazonian rain forest soil: Continuous measurements of NO flux and soil compensation concentration, J. Geophys. Res., 107(D20), 8057, doi:10.1029/2001JD000521, 2002a.

Gut, A., Scheibe, M., Rottenberger, S., Rummel, U., Welling, M., Ammann, C., Kirkman, G. A., Kuhn, U., Meixner, F. X., Kesselmeier, J., Lehmann, B. E., Schmidt, J., Müller, E., and Piedade, M. T. F.: Exchange fluxes of $\mathrm{NO}_{2}$ and $\mathrm{O}_{3}$ at soil and leaf surfaces in an Amazonian rain-forest, J. Geophys. Res., 107(D20), 8060, doi:10.1029/2001JD000654, 2002b.

Hicks, B. B., Baldocchi, D. D., Meyers, T. P., Hosker, R. P., and Matt, D. R.: A preliminary multiple resistance routine for deriving dry deposition velocities from measured quantities, Water Air and Soil Pollution, 36(3-4), 311-330, 1987.

Hodnett, M. G., Oyama, M. D., Tomasella, J., and Marques Filho, A. d. O.: Comparisons of long-term soil water storage behaviour under pasture and forest in three areas of Amazonia, in: Amazonian deforestation and climate, edited by: Gash, J. H. C., Nobre, C. A., Roberts, J. M., and Victoria, R. L., pp. 57-77, John Wiley \& Sons, Chichester, 1996. 
Horst, T. W.: On frequency response corrections for eddy covariance flux measurements, Bound.-Lay. Meteorol., 94(3), 517$520,2000$.

Jacob, D. J. and Wofsy, S. C.: Photochemistry of biogenic emissions over the Amazon forest, J. Geophys. Res., 93(D2), 1477-1486, 1988.

Jacob, D. J. and Wofsy, S. C.: Budgets of reactive nitrogen, hydrocarbons, and ozone over the Amazon-Forest during the wet season, J. Geophys. Res., 95(D10), 16 737-16 754, 1990.

Jarvis, P. G.: The interpretation of the variations in leaf water potential and stomatal conductance found in canopies in the field, Philosophical Transactions of the Royal Society of London B, 373, 593-610, 1976.

Kaimal, J. C., Wyngaard, J. C., Izumi, Y., and Cote, O. R.: Spectral characteristics of surface-layer turbulence, Q. J. Roy. Meteor. Soc., 98, 563-589, 1972.

Kaplan, W. A., Wofsy, S. C., Keller, M., and da Costa, J. M.: Emission of $\mathrm{NO}$ and deposition of $\mathrm{O}_{3}$ in a tropical forest system, J. Geophys. Res., 93(D2), 1389-1395, 1988.

Kirchhoff, V. W. J. H., Browell, E. V., and Gregory, G. L.: Ozone measurements in the troposphere of an Amazonian rain forest environment, J. Geophys. Res., 93(D12), 15 850-15 860, 1988.

Kirchhoff, V. W. J. H., Dasilva, I. M. O., and Browell, E. V.: Ozone measurements in Amazonia - dry season versus wet season, J. Geophys. Res., 95(D10), 16 913-16926, 1990.

Kirchhoff, V. W. J. H., Alves, J. R., da Silva, F. R., and Fishman, J.: Observations of ozone concentratios in the Brazilian cerrado during the TRACE A field expedition, J. Geophys. Res., 101(D19), 24 029-24042, 1996.

Kirkman, G. A., Gut, A., Ammann, C., Gatti, L. V., Cordova, A. M., Moura, M. A. L., Andreae, M. O., and Meixner, F. X.: Surface exchange of nitric oxide, nitrogen dioxide, and ozone at a pasture in Rondonia, Brazil, J. Geophys. Res., 107(D20), 8083, doi:10.1029/2001JD000523, 2002.

Kristensen, L.: Time series analysis. Dealing with imperfect data, Riso National Laboratory, Roskilde, Denmark, 1998.

Kruijt, B., Lloyd, J., Grace, J., McIntyre, J. A., Farquhar, G. D., Miranda, A. C., and McCracken, P.: Sources and sinks of $\mathrm{CO}_{2}$ in Rondonia tropical rainforest, in: Amazonian deforestation and climate, edited by: Gash, J. H. C., Nobre, C. A., Roberts, J. M., and Victoria, R. L., pp. 331-351, John Wiley \& Sons, Chichester, 1996.

Laisk, A., Kull, O., and Moldau, H.: Ozone concentration in leaf intercellular air spaces is close to zero, Plant Physiol., 90, 11631167, 1989.

Lamaud, E., Carrara, A., Brunet, Y., Lopez, A., and Druilhet, A.: Ozone fluxes above and within a pine forest canopy in dry and wet conditions, Atmos. Environ., 36, 77-88, 2002.

Lenschow, D. H. and Kristensen, L.: Uncorrelated noise in turbulence measurements, J. Atmos. Oceanic Technol., 2, 68-81, 1985.

Lenschow, D. H. and Raupach, M. R.: The attenuation of fluctuations in scalar concentrations through sampling tubes, J. Geophys. Res., 96(D8), 15 259-15 268, 1991.

Logan, J. A. and Kirchhoff, V. W. J. H.: Seasonal variations of tropospheric ozone at Natal, Brazil, J. Geophys. Res., 91(D7), 7875-7881, 1986.

Malhi, Y., Nobre, A. D., Grace, J., Kruijt, B., Pereira, M. G. P., Culf, A., and Scott, S. L.: Carbon dioxide transfer over a central Ama- zonian rain forest, J. Geophys. Res., 103(D24), 31 593-31 612, 1998.

Matsuda, K., Watanabe, I., Wingpud, V., Theramonkol, P., Khummongkol, P., Wangwongwatana, S., and Totsuka, T.: Ozone dry deposition above a tropical forest in the dry season in northern Thailand, Atmos. Environ., 39, 2571-2577, 2005.

McWilliam, A.-L. C., Cabral, O. M. R., Gomes, B. M., Esteves, J. L., and Roberts, J. M.: Forest and pasture leaf gas exchange in south-west Amazonia, in Amazonian deforestation and climate, edited by: Gash, J. H. C., Nobre, C. A., Roberts, J. M., and Victoria, R. L., pp. 266-285, John Wiley \& Sons, Chichester, 1996.

Meixner, F. X., Fickinger, T., Marufu, L., Mukurumbira, L., Makina, E., Nathaus, F. J., Serca, D., and Andreae, M. O.: Preliminary results on nitric oxide emission from a southern African savanna ecosystem, Nutrient Cycling in Agroecosystems, 48, 123138, 1997.

Moncrieff, J. B., Massheder, J. M., deBruin, H., Elbers, J., Friborg, T., Heusinkveld, B., Kabat, P., Scott, S., Soegaard, H., and Verhoef, A.: A system to measure surface fluxes of momentum, sensible heat, water vapour and carbon dioxide, J. Hydrol., 188-189, 589-611, 1997.

Monteith, J. L. and Unsworth, M. H.: Principles of environmental physics, 291 pp., Edward Arnold, London, 1990.

Moore, C. J.: Frequency response correction for eddy correlation systems, Boundary-Layer Meteorol., 37, 17-35, 1986.

Munger, W. J., Wofsy, S. C., Bakwin, P. S., Fan, S. M., Goulden, M. L., Daube, B. C., Goldstein, A. H., Moore, K. E., and Fitzjarrald, D. R.: Atmospheric deposition of reactive nitrogen oxides and ozone in a temperate decidous forest and subarctic woodland. 1. Measurements and mechanisms, J. Geophys. Res., 101(D7), 12 639-12 657, 1996.

Nobre, C. A., Fisch, G., da Rocha, H. R., Lyra, R. F. d. F., da Rocha, E. P., da Costa, A. C. L., and Ubarana, V. N.: Observations of the atmospheric boundary layer in Rondônia, in: Amazonian deforestation and climate, edited by: Gash, J. H. C., Nobre, C. A., Roberts, J. M., and Victoria, R. L., pp. 413-423, John Wiley \& Sons, Chichester, 1996.

Raupach, M. and Shaw, R. H.: Averaging procedures for flow within vegetation canopies, Bound.-Lay. Meteorol., 22, 79-90, 1982.

Raupach, M. R.: Simplified expressions for vegetation roughness length and zero-plane pisplacement as functions of canopy height and area index, Bound.-Lay. Meteor., 71(1-2), 211-216, 1994.

Roberts, D. A., Numata, I., Holmes, K., Batista, G., Krug, T., Monteiro, A., Powell, B., and Chadwick, O. A.: Large scale mapping of land-cover change in Rondônia using multitemporal spectral mixture analysis and decision tree classifiers, J. Geophys. Res., 107(D20), 8073, doi:10.1029/2001JD000374, 2002.

Rottenberger, S., Kuhn, U., Wolf, A., Schebeske, G., Oliva, S. T., Tavares, T. M., and Kesselmeier, J.: Formaldehyde and acetaldehyde exchange during leaf development of the Amazonian deciduous tree species Hymeaea courbaril, Atmos. Environ., 39(12), 2275-2279, 2005.

Rummel, U., Ammann, C., Gut, A., Meixner, F. X., and Andreae, M. O.: Eddy covariance measurements of nitric oxide flux within an Amazonian rainforest, J. Geophys. Res., 107(D20), 8050, doi:10.1029/2001JD000520, 2002.

Rummel, U.: Turbulent exchange of ozone and nitrogen oxides be- 
tween an Amazonian rain forest and the atmosphere, Dissertation Thesis, University of Bayreuth, available at: http://opus.ub. unibayreuth.de/volltexte/2006/243/ 2005.

Schmid, H. P.: Source Areas for Scalars and Scalar Fluxes, Boundary-Layer Meteorology, 67, 293-318, 1994.

Sigler, J. M., Fuentes, J. D., Heitz, R. C., Garstang, M., and Fisch, G.: Ozone dynamics and deposition processes at a deforested site in the Amazon basin, Ambio, 31(1), 21-27, 2002.

Webb, E. K., Pearman, G. I., and Leuning, R.: Correction of flux measurements for density effects due to heat and water vapour transfer, Q. J. Roy. Meteor. Soc., 106, 85-100, 1980.
Wright, I. R., Gash, J. H. C., da Rocha, H. R., and Roberts, J. M.: Modelling surface conductance for Amazonian pasture and forest, in: Amazonian deforestation and climate, edited by: Gash, J. H. C., Nobre, C. A., Roberts, J. M., and Victoria, R. L., pp. 437-457, John Wiley \& Sons, Chichester, 1996.

Zeller, K., Massman, W., Stocker, D., Fox, D. G., Stedman, D., and Hazlett, D.: Initial results from the Pawnee eddy correlation system for dry acid deposition research, United States Department of Agriculture (USDA), Forest Service, RM-282, 1989.

Zhang, L., Brook, J. R., and Vet, R.: On ozone dry depositionwith emphasis on non-stomatal uptake and wet canopies, Atmos. Environ., 36, 4787-4799, 2002. 